University of New Hampshire

University of New Hampshire Scholars' Repository

Faculty Publications

$10-1-2002$

\title{
DIRECT ESTIMATION OF ABOVEGROUND FOREST PRODUCTIVITY THROUGH HYPERSPECTRAL REMOTE SENSING OF CANOPY NITROGEN
}

\author{
Marie-Louise Smith \\ USDA Forest Service \\ Scott V. Ollinger \\ University of New Hampshire, Durham, scott.ollinger@unh.edu \\ Mary E. Martin \\ University of New Hampshire, Durham, mary.martin@unh.edu \\ John D. Aber \\ University of New Hampshire, Durham, john.aber@unh.edu \\ Richard A. Hallett \\ USDA Forest Service
}

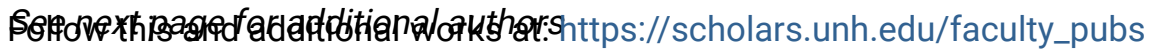 \\ Comments \\ This is an article published by Ecological Society of America (ESA) in Ecological Applications in 2002, available online: https://dx.doi.org/10.1890/1051-0761(2002)012[1286:DEOAFP]2.0.C0;2}

\section{Recommended Citation}

Smith, M.L., S.V. Ollinger, M.E. Martin, J.D. Aber, C.L. Goodale. 2002. DIRECT ESTIMATION OF ABOVEGROUND FOREST PRODUCTIVITY THROUGH HYPERSPECTRAL REMOTE SENSING OF CANOPY NITROGEN. Ecological Applications, 12(5): 1286-1302.

This Article is brought to you for free and open access by University of New Hampshire Scholars' Repository. It has been accepted for inclusion in Faculty Publications by an authorized administrator of University of New Hampshire Scholars' Repository. For more information, please contact Scholarly.Communication@unh.edu. 


\section{Authors}

Marie-Louise Smith, Scott V. Ollinger, Mary E. Martin, John D. Aber, Richard A. Hallett, and Christine L. Goodale 


\title{
DIRECT ESTIMATION OF ABOVEGROUND FOREST PRODUCTIVITY THROUGH HYPERSPECTRAL REMOTE SENSING OF CANOPY NITROGEN
}

\author{
Marie-Louise Smith, ${ }^{1,3}$ Scott V. Ollinger, ${ }^{2}$ Mary E. Martin, ${ }^{2}$ John D. Aber, ${ }^{2}$ \\ Richard A. Hallett, ${ }^{1}$ And Christine L. Goodale ${ }^{2}$ \\ ${ }^{1}$ USDA Forest Service, Northeastern Research Station, Durham, New Hampshire 03824 USA \\ ${ }^{2}$ Complex Systems Research Center, University of New Hampshire, Durham, New Hampshire 03824 USA
}

\begin{abstract}
The concentration of nitrogen in foliage has been related to rates of net photosynthesis across a wide range of plant species and functional groups and thus represents a simple and biologically meaningful link between terrestrial cycles of carbon and nitrogen. Although foliar $\mathrm{N}$ is used by ecosystem models to predict rates of leaf-level photosynthesis, it has rarely been examined as a direct scalar to stand-level carbon gain. Establishment of such relationships would greatly simplify the nature of forest $\mathrm{C}$ and $\mathrm{N}$ linkages, enhancing our ability to derive estimates of forest productivity at landscape to regional scales. Here, we report on a highly predictive relationship between whole-canopy nitrogen concentration and aboveground forest productivity in diverse forested stands of varying age and species composition across the 360 000-ha White Mountain National Forest, New Hampshire, USA. We also demonstrate that hyperspectral remote sensing can be used to estimate foliar $\mathrm{N}$ concentration, and hence forest production across a large number of contiguous images. Together these data suggest that canopy-level $\mathrm{N}$ concentration is an important correlate of productivity in these forested systems, and that imaging spectrometry of canopy $\mathrm{N}$ can provide direct estimates of forest productivity across large landscapes.
\end{abstract}

Key words: foliar chemistry; forest $C$ and $N$ linkages; forest canopy-level $N$ concentration; forest productivity; nitrogen; remote sensing, hyperspectral, AVIRIS; White Mountain National Forest, New Hampshire, USA.

\section{INTRODUCTION}

The identification of temperate forests as potentially important sinks for atmospheric $\mathrm{CO}_{2}$ (Houghton et al. 1999, Battle et al. 2000) has made estimation of forest biomass production a critical component of globalchange forecasting. Despite this, obtaining accurate, spatially explicit estimates of forest growth rates over large areas is an exceedingly difficult task due to finescale variation resulting from natural environmental heterogeneity overlain by complex patterns of human land use (Fung 1997, Schimel et al. 1997, Scurlock et al. 1999).

A number of field studies across diverse biomes have documented strong linkages among foliar chemistry, particularly nitrogen concentration on a mass basis, and rates of net photosynthesis (Field and Mooney 1986, Reich et al. 1999a) and soil N availability (Pastor et al. 1984, Yin 1992, Scott and Binkley 1997, Ollinger et al. 2002). These results are indicative of the tightly coupled nature of $\mathrm{C}$ and $\mathrm{N}$ dynamics in N-limited systems (Aber et al. 1991, Reich et al. 1997) and suggest that foliar $\mathrm{N}$ concentration could provide a useful indicator of ecosystem productivity, and one that could be used to capture fine-scale variation in this process, if a method were available to measure the $\mathrm{N}$ content

Manuscript received 1 September 2000; revised 13 July 2001; accepted 17 December 2001.

${ }^{3}$ E-mail: marielouisesmith@fs.fed.us of foliage with high spatial resolution over large areas. Despite this potential, such relationships have rarely been investigated. A number of studies have demonstrated relationships between foliar $\mathrm{N}$ content and forest productivity among a number of species, primarily coniferous (Van Cleve et al. 1983, Comeau and Kimmins 1986, Matson et al. 1994, Bauer et al. 1997), but no widely acknowledged pattern of whole-canopy foliar chemistry vs. metrics of forest production have emerged.

Similarly, the remote sensing of foliar chemistry has been generally restricted to small experimental areas. While the use of high-spectral-resolution reflectance methods for the direct measurement of nitrogen, lignin, cellulose, and other chemical constituents of foliage has become an accepted laboratory technique (e.g., Hallett et al. 1997, Martin and Aber 1997, Gillon et al. 1999), general applications of high-spectral-resolution remote sensing to the measurement of whole-canopy chemistry have been limited (Wessman et al. 1988, Matson et al. 1994, Zagolski et al. 1996, Martin and Aber 1997). Application of a single calibration equation across multiple contiguous images covering a large, forested landscape has not been achieved.

Here we present the first direct estimates of forest productivity across a large, complex forested landscape developed by estimating whole-canopy foliar N concentrations from high-resolution imaging spectrometry. These estimates are based upon a strong three-way 


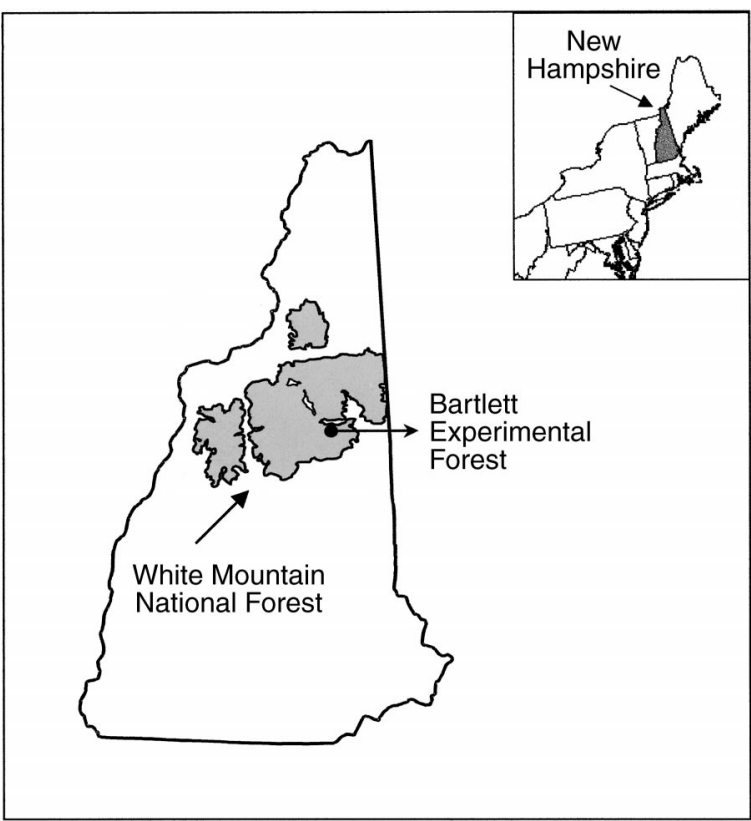

FIG. 1. Location of White Mountain National Forest, New Hampshire, USA, and the Bartlett Experimental Forest, Bartlett, New Hampshire, USA.

relationship among measured canopy $\mathrm{N}$ concentration measured wood and foliar production, and the remotesensing signals for a diverse and spatially extensive set of field sites.

\section{Methods \\ Study area}

Our research was conducted in the White Mountain National Forest (WMNF), New Hampshire, USA (Fig. 1 ). The WMNF is a 364485 -ha heavily forested and mountainous region ranging from $200 \mathrm{~m}$ to more than $1400 \mathrm{~m}$ in elevation. Because of its wide elevational and climatic range, the WMNF includes a variety of vegetation and site types representative of those present across most of the northeastern United States. These include oak-pine-dominated stands in valley bottoms on lacustrine and glacio-fluvial substrates, northernhardwood- and mixed-conifer-dominated mid-slopes on basal and ablational tills, spruce-fir forest types on upper mountain slopes, and alpine tundra mountaintops. Soils are mostly coarse textured spodosols or inceptisols formed on glacially deposited tills. Sandy outwash is common in valley bottoms and shallow bedrock histosols may be found on upper mountain slopes. The climate of the White Mountains is characterized by a relatively short growing season (frost-free period of $\sim 120-140$ d) and long, cold winters. Air temperatures average $-12^{\circ} \mathrm{C}$ and $19^{\circ} \mathrm{C}$ in January and July, respectively. Precipitation is generally evenly distributed throughout the year and averages $120-140 \mathrm{~cm}$, with about one third in the form of snow (Federer et al. 1990).
This study examined relationships among forest productivity, canopy biomass and leaf-area index (LAI), and foliar nitrogen content and concentration in diverse forested stands across the WMNF. In addition, we also examined forest canopy $\mathrm{N}$ concentration in relation to canopy-level spectral response as measured by a highaltitude airborne imaging spectrometer to determine the potential for remote estimation across a large forested landscape. All stands were long-term forest growth inventory plots maintained by the USDA Forest Service. Forty-eight plots were located at the 1025-ha Bartlett Experimental Forest (BEF), Bartlett, New Hampshire (Fig. 1) and 37 plots, part of the USDA Forest Service Northeastern Forest Inventory and Analysis (FIA) plot network, were widely distributed across the White Mountain National Forest, for a total of 85 plots. Plots represent a broad range of species composition and successional status. Species represented include American beech (Fagus grandifolia Ehrh.), sugar maple (Acer saccharum Marsh.), yellow birch (Betula alleghaniensis Britt.), red maple (Acer rubrum L.), white ash (Fraxinus americana L.), red oak (Quercus rubra L.), pin cherry (Prunus pennsylvanica L.), paper birch (Betula papyrifera Marsh.), red spruce (Picea rubens Sarg.), balsam fir (Abies balsamea (L.) Miller), eastern hemlock (Tsuga canadensis (L.) Carr.), and eastern white pine (Pinus strobus L.). Most stands contained mixtures of two or more species. Plot elevations range from roughly $300-800 \mathrm{~m}$.

\section{Field data collection and analysis}

All 85 forest stands were sampled for leaf-level and whole-canopy nitrogen concentration for remote-sensing image calibration. Fifty-six of these stands were sampled for aboveground woody biomass production (wood production) and 18 of these were also measured for foliar biomass production and leaf-area index (Table $1)$.

Forest productivity.-Wood biomass was estimated by measurements of stem diameter for all trees greater than $5 \mathrm{~cm}$ diameter at breast height (dbh), and converted to biomass values with previously derived allometric equations for the species included in our study. We only used equations that were developed in the northeastern region and that included algorithms for both stem and branch biomass (Tritton and Hornbeck 1981, Hocker and Early 1983). Wood biomass (in grams per square meter) for each plot was calculated by summing individual tree values over the entire plot and dividing by the plot area. Plot-level wood production (in grams per square meter per year) was calculated as the difference between woody biomass in the most recent and previous inventory, divided by the time interval over which they were sampled.

For all 56 plots used for wood production measurement, the most recent biomass inventory was conducted by us in 1998. For previous measurements, we made use of data collected by several USDA Forest Service 
TABLE 1. Results of field data collection from sample plots in 85 forest stands located across the White Mountain National Forest, New Hampshire, USA.

\begin{tabular}{|c|c|c|c|c|c|c|}
\hline \multirow[b]{2}{*}{$\begin{array}{l}\text { Loca- } \\
\text { tion } †\end{array}$} & Plot & \multicolumn{3}{|c|}{$\begin{array}{l}\text { Productivity } \\
\left(\mathrm{g} \cdot \mathrm{m}^{-2} \cdot \mathrm{yr}^{-1}\right)\end{array}$} & \multirow[b]{2}{*}{ LAI } & \multirow{2}{*}{$\begin{array}{c}\text { Canopy } \\
\mathrm{N} \\
(\mathrm{g} / 100 \mathrm{~g})\end{array}$} \\
\hline & Main species & Wood & $\begin{array}{l}\text { Litter- } \\
\text { fall }\end{array}$ & Total & & \\
\hline $\mathrm{BEF}$ & Hemlock & 238 & $\ldots$ & $\ldots$ & $\ldots$ & 1.20 \\
\hline $\mathrm{BEF}$ & Hemlock & 226 & 176 & 402 & 3.09 & 1.20 \\
\hline $\mathrm{BEF}$ & Hemlock & 303 & $\cdots$ & $\cdots$ & $\ldots$ & 1.28 \\
\hline $\mathrm{BEF}$ & Hemlock & 294 & $\cdots$ & $\cdots$ & $\cdots$ & 1.35 \\
\hline $\mathrm{BEF}$ & Hemlock-Red spruce & 248 & 149 & 397 & 2.78 & 1.09 \\
\hline $\mathrm{BEF}$ & Hemlock-Beech & 357 & $\cdots$ & $\cdots$ & $\ldots$ & 1.69 \\
\hline FIA & Hemlock-Beech-Yellow birch & 301 & $\ldots$ & $\ldots$ & $\ldots$ & 1.73 \\
\hline FIA & Hemlock-Yellow birch-Beech & $\cdots$ & $\cdots$ & $\ldots$ & $\cdots$ & 1.77 \\
\hline FIA & Hemlock-Red maple & $\ldots$ & $\ldots$ & $\ldots$ & $\ldots$ & 1.58 \\
\hline FIA & Hemlock-Red maple & ... & $\ldots$ & $\ldots$ & $\ldots$ & 1.70 \\
\hline $\mathrm{BEF}$ & Red spruce & 66 & 54 & 120 & 1.73 & 0.88 \\
\hline $\mathrm{BEF}$ & Red spruce & 165 & 59 & 224 & 1.82 & 1.11 \\
\hline $\mathrm{BEF}$ & Red spruce & 229 & 51 & 280 & 1.80 & 1.15 \\
\hline $\mathrm{BEF}$ & Red spruce & 217 & 70 & 287 & 1.90 & 1.17 \\
\hline $\mathrm{BEF}$ & Red spruce & 252 & $\cdots$ & $\ldots$ & $\cdots$ & 1.21 \\
\hline FIA & Red spruce-Balsam fir & $\ldots$ & $\ldots$ & $\ldots$ & $\ldots$ & 1.51 \\
\hline FIA & Red spruce-Balsam fir-Red maple & 284 & ... & $\ldots$ & $\ldots$ & 1.46 \\
\hline FIA & Red spruce-Hemlock & 187 & $\ldots$ & $\ldots$ & $\ldots$ & 1.22 \\
\hline $\mathrm{BEF}$ & Red spruce-Paper birch & 237 & 186 & 423 & 2.58 & 1.26 \\
\hline $\mathrm{BEF}$ & White pine-Hardwood & 286 & 256 & 542 & 3.46 & 1.73 \\
\hline $\mathrm{BEF}$ & White pine-Hardwood & 348 & 267 & 615 & 3.61 & 1.74 \\
\hline $\mathrm{BEF}$ & Beech & 341 & 190 & 531 & 3.04 & 1.87 \\
\hline $\mathrm{BEF}$ & Beech & 421 & $\ldots$ & $\ldots$ & $\ldots$ & 2.08 \\
\hline $\mathrm{BEF}$ & Beech & 400 & $\ldots$ & $\ldots$ & $\ldots$ & 2.15 \\
\hline $\mathrm{BEF}$ & Beech & 416 & 239 & 655 & 3.49 & 2.15 \\
\hline $\mathrm{BEF}$ & Beech & 462 & $\ldots$ & $\ldots$ & $\ldots$ & 2.21 \\
\hline $\mathrm{BEF}$ & Beech & 470 & $\cdots$ & $\cdots$ & $\ldots$ & 2.21 \\
\hline $\mathrm{BEF}$ & Beech & 488 & $\ldots$ & $\ldots$ & $\ldots$ & 2.48 \\
\hline $\mathrm{BEF}$ & Beech-Hemlock & 304 & $\ldots$ & $\ldots$ & $\ldots$ & 1.61 \\
\hline FIA & Beech-Paper birch & 306 & $\ldots$ & $\ldots$ & $\ldots$ & 1.90 \\
\hline FIA & Beech-Paper birch-Red maple & 452 & $\ldots$ & $\ldots$ & $\ldots$ & 2.39 \\
\hline $\mathrm{BEF}$ & Beech-Red maple & 386 & $\cdots$ & $\ldots$ & $\ldots$ & 2.12 \\
\hline $\mathrm{BEF}$ & Beech-Red oak & 445 & $\ldots$ & $\ldots$ & $\ldots$ & 2.05 \\
\hline $\mathrm{BEF}$ & Beech-Red oak & 404 & 191 & 595 & 3.33 & 2.14 \\
\hline FIA & Beech-Sugar maple & $\cdots$ & $\cdots$ & $\cdots$ & $\cdots$ & 2.23 \\
\hline FIA & Beech-Sugar maple & $\ldots$ & $\ldots$ & $\ldots$ & $\ldots$ & 2.34 \\
\hline FIA & Paper birch-Balsam fir & $\ldots$ & $\ldots$ & $\ldots$ & $\ldots$ & 1.77 \\
\hline FIA & Paper birch-Balsam fir-Red spruce & $\ldots$ & $\cdots$ & $\ldots$ & $\ldots$ & 1.66 \\
\hline $\mathrm{BEF}$ & Paper birch-Beech & 502 & $\ldots$ & $\ldots$ & $\ldots$ & 2.26 \\
\hline $\mathrm{BEF}$ & Paper birch-Beech & 501 & 251 & 752 & 3.39 & 2.34 \\
\hline FIA & Paper birch-Beech & $\ldots$ & $\ldots$ & $\ldots$ & $\ldots$ & 1.56 \\
\hline FIA & Paper birch-Red maple & $\ldots$ & $\ldots$ & $\ldots$ & $\ldots$ & 1.91 \\
\hline FIA & Paper birch-Striped maple & $\cdots$ & ... & $\ldots$ & $\ldots$ & 2.10 \\
\hline FIA & Paper birch-Sugar maple & $\cdots$ & $\ldots$ & $\ldots$ & $\ldots$ & 2.28 \\
\hline FIA & Paper birch-Yellow birch & $\ldots$ & $\ldots$ & $\ldots$ & $\ldots$ & 1.76 \\
\hline FIA & Yellow birch-Balsam fir-Red spruce & $\cdots$ & ... & $\ldots$ & $\ldots$ & 1.70 \\
\hline FIA & Yellow birch-Red spruce-Balsam fir & $\ldots$ & $\ldots$ & $\ldots$ & $\ldots$ & 1.84 \\
\hline $\mathrm{BEF}$ & Yellow birch-Beech & 319 & $\ldots$ & $\ldots$ & $\ldots$ & 1.98 \\
\hline $\mathrm{BEF}$ & Yellow birch-Beech & 465 & .. & $\ldots$ & $\ldots$ & 2.39 \\
\hline FIA & Yellow birch-Paper birch & $\ldots$ & $\ldots$ & $\ldots$ & $\ldots$ & 2.24 \\
\hline FIA & Yellow birch-Paper birch-Beech & $\ldots$ & $\ldots$ & $\ldots$ & $\ldots$ & 2.27 \\
\hline FIA & Yellow birch-Red spruce & $\ldots$ & $\ldots$ & $\ldots$ & $\ldots$ & 1.51 \\
\hline FIA & Yellow birch-Sugar maple & $\ldots$ & $\cdots$ & $\ldots$ & $\cdots$ & 2.18 \\
\hline FIA & Yellow birch-Sugar maple & $\ldots$ & $\ldots$ & $\ldots$ & $\ldots$ & 2.24 \\
\hline $\mathrm{BEF}$ & Red maple & 360 & $\ldots$ & $\ldots$ & $\ldots$ & 1.99 \\
\hline $\mathrm{BEF}$ & Red maple & 348 & $\ldots$ & $\ldots$ & $\ldots$ & 2.07 \\
\hline FIA & Red maple-Beech & 320 & $\ldots$ & $\ldots$ & $\ldots$ & 1.85 \\
\hline $\mathrm{BEF}$ & Red maple-Beech & 375 & 228 & 603 & 3.35 & 1.86 \\
\hline $\mathrm{BEF}$ & Red maple-Beech & 328 & $\cdots$ & $\ldots$ & $\ldots$ & 1.91 \\
\hline FIA & Red maple-Beech & $\cdots$ & $\ldots$ & $\ldots$ & $\ldots$ & 1.96 \\
\hline FIA & Red maple-Beech & 373 & $\cdots$ & $\ldots$ & $\ldots$ & 2.36 \\
\hline $\mathrm{BEF}$ & Red maple-Paper birch & 331 & $\cdots$ & $\ldots$ & $\ldots$ & 1.67 \\
\hline $\mathrm{BEF}$ & Red maple-Paper birch & 286 & $\ldots$ & $\ldots$ & $\ldots$ & 1.70 \\
\hline $\mathrm{BEF}$ & Red maple-White pine & 401 & $\cdots$ & $\ldots$ & $\ldots$ & 1.96 \\
\hline FIA & Red maple-Yellow birch & $\ldots$ & $\ldots$ & $\ldots$ & $\ldots$ & 2.03 \\
\hline
\end{tabular}


TABle 1. Continued.

\begin{tabular}{|c|c|c|c|c|c|c|}
\hline \multicolumn{2}{|c|}{ Plot } & \multicolumn{3}{|c|}{$\begin{array}{l}\text { Productivity } \\
\left(\mathrm{g} \cdot \mathrm{m}^{-2} \cdot \mathrm{yr}^{-1}\right)\end{array}$} & \multirow[b]{2}{*}{ LAI } & \multirow{2}{*}{$\begin{array}{c}\text { Canopy } \\
N \\
(\mathrm{~g} / 100 \mathrm{~g})\end{array}$} \\
\hline $\begin{array}{l}\text { Loca- } \\
\text { tion } \dagger\end{array}$ & Main species & Wood & $\begin{array}{l}\text { Litter- } \\
\text { fall }\end{array}$ & Total & & \\
\hline FIA & Sugar maple & $\ldots$ & $\ldots$ & $\ldots$ & $\ldots$ & 2.08 \\
\hline FIA & Sugar maple-Beech & 260 & 236 & 496 & 3.58 & 1.70 \\
\hline FIA & Sugar maple-Beech & 260 & $\ldots$ & $\ldots$ & $\ldots$ & 1.90 \\
\hline FIA & Sugar maple-Beech & & $\ldots$ & $\ldots$ & $\ldots$ & 1.91 \\
\hline $\mathrm{BEF}$ & Sugar maple-Beech & 435 & $\ldots$ & $\ldots$ & $\ldots$ & 1.98 \\
\hline $\mathrm{BEF}$ & Sugar maple-Beech & 396 & $\ldots$ & $\ldots$ & $\ldots$ & 1.98 \\
\hline BEF & Sugar maple-Beech & 368 & 197 & 565 & 3.52 & 1.99 \\
\hline $\mathrm{BEF}$ & Sugar maple-Beech & 446 & $\ldots$ & $\ldots$ & $\ldots$ & 2.03 \\
\hline FIA & Sugar maple-Beech & & $\ldots$ & $\ldots$ & $\ldots$ & 2.10 \\
\hline BEF & Sugar maple-Beech & 462 & 213 & 675 & 3.34 & 2.12 \\
\hline $\mathrm{BEF}$ & Sugar maple-Beech & 424 & $\ldots$ & $\ldots$ & $\ldots$ & 2.18 \\
\hline $\mathrm{BEF}$ & Sugar maple-Beech & 481 & $\ldots$ & $\ldots$ & $\ldots$ & 2.21 \\
\hline FIA & Sugar maple-Beech & 354 & $\ldots$ & $\ldots$ & $\ldots$ & 2.29 \\
\hline FIA & Sugar maple-Beech & 488 & $\ldots$ & $\ldots$ & $\ldots$ & 2.31 \\
\hline FIA & Sugar maple-Beech-Red maple & 291 & $\ldots$ & $\ldots$ & $\ldots$ & 1.82 \\
\hline $\mathrm{BEF}$ & Sugar maple-White ash & 383 & 224 & 607 & 3.47 & 2.01 \\
\hline FIA & Sugar maple-White ash & $\ldots$ & $\ldots$ & $\ldots$ & $\ldots$ & 2.17 \\
\hline FIA & Sugar maple-White ash & $\ldots$ & $\ldots$ & $\ldots$ & $\ldots$ & 2.20 \\
\hline FIA & Sugar maple-Yellow birch & $\ldots$ & $\ldots$ & $\ldots$ & $\ldots$ & 2.16 \\
\hline FIA & Sugar maple-Yellow birch-Beech & $\ldots$ & $\ldots$ & $\ldots$ & $\ldots$ & 2.02 \\
\hline
\end{tabular}

Notes: All 85 forest stands were sampled for leaf-level and whole-canopy nitrogen concentration, measured as grams of $\mathrm{N}$ per 100 grams foliar biomass; 56 stands were sampled for aboveground wood biomass production (wood), and 18 of those stands were also measured for foliar biomass production (Litterfall) and leaf-area index (LAI).

$\dagger$ Plot key: BEF = plot located at the Bartlett Experimental Forest, Bartlett, New Hampshire, USA; FIA = plot part of USDA Forest Service Forest Inventory and Analysis plot network located across the White Mountain National Forest, New Hampshire, USA.

forest inventory programs. At the BEF, all plots were previously measured in 1991-1992 as part of a periodic survey (Leak and Smith 1996). FIA plots used in this study were last measured in 1980 as part of the New Hampshire statewide survey. These plots are no longer part of the current FIA plot base in New Hampshire, and had not been remeasured until our 1998 survey.

BEF and FIA plots differed in both plot size and in inventory approach. Plots located at the BEF were 0.1 ha in size and FIA plots were 0.08 ha in size. BEF plots used in this study were originally established in 1931-1932, FIA plots were variously established before 1959. We chose to adopt the plot size and follow the measurement protocols for each plot type in order to make use of data collected in previous inventories for calculation of biomass increment.

Periodic growth inventory at the BEF was based on dbh measurement in each plot of all standing live stems $>3.8-\mathrm{cm}$ dbh (1.5 inches in original dbh units) measured in 2.54-cm (1-inch) size classes. For example, the smallest size class, $5 \mathrm{~cm}$ ( 2 inches), includes all stems with dbh between $3.8 \mathrm{~cm}$ (1.5 inches) and 6.4 $\mathrm{cm}$ (2.5 inches). Data were recorded as a tally by species and size class. Tree mortality was included as a component of annual biomass increment in our remeasurement and was estimated for BEF plots based on difference in number of live and dead stems by species and size class between inventory periods $(1991,1998)$ after accounting for growth of stems into larger size classes. This method is similar to that described by Clark et al. (2001) as the "Approach 2" strategy for field estimation of forest production.

FIA growth inventory was based on dbh measurement to the nearest 0.1 inch of each uniquely identified tree (numbered with metal tags and referenced by distance and azimuth from the plot center) (Hansen et al. 1992). For remeasurement of FIA plots, we relocated and measured dbh for each tagged tree, living or dead, from the previous inventory, as well as the dbh of stem in-growth during the intervening period. In a very few cases certain individual trees from the previous inventory could not be relocated; these were still included in the biomass increment calculation but at their diameter from the 1980 inventory. This method of carrying dead trees forward with zero growth prevents mortality from causing a downward bias in growth estimates. The individual tree remeasurement method is described by Clark et al. (2001) as the "Approach 1" strategy for field estimation of forest production.

Foliar biomass production was estimated on a subset of 18 plots (shown in Table 1) by collection of leaf litterfall. Eight litter baskets $\left(0.23 \mathrm{~m}^{2}\right)$ were randomly placed in selected plots during the late summer of 1996. Litter was collected every two to three weeks in the fall, once in the spring, and once in late summer of 1997; these samples were composited into a single sample per litterbasket prior to sorting. Litter from each basket was air dried and sorted into leaf and non-leaf 
litter. Leaf litter was sorted by species and then oven dried at $70^{\circ} \mathrm{C}$ for $48 \mathrm{~h}$ and weighed. Annual foliar production (in grams per square meter per year) was calculated as the sum of litter-basket foliar mass divided by litter-basket area.

Aboveground net primary productivity (ANPP, in grams per square meter per year) was calculated as the sum of wood production and annual litterfall biomass production for the 18 plots where both variables were measured.

Although wood production measurements would ideally have been collected on all 56 productivity-measurement plots over similar time intervals, and foliar production over the time intervals and number of plots that matched those of wood production measurements, we were constrained by the availability of historical woody biomass data and the logistical difficulties of frequent litterfall sampling in remote locations.

Canopy foliar mass (in grams per square meter) was estimated by combining leaf litterfall data with estimates of leaf retention time. Because broad-leaved deciduous trees shed all of their leaves each year (leaf retention time $=1 \mathrm{yr}$ ), foliar mass and foliar production are equivalent. For needle-leaved evergreens, foliar mass was calculated by multiplying annual litterfall mass by species-specific average leaf longevity as taken from the literature to account for leaves retained for more than one season. We recognize that the ratio of leaf production to litterfall in evergreen-dominated forests is not always equivalent from year to year and so measurements based on a single year's litterfall may underestimate or overestimate long-term mean leaf production (Gower et al. 1999, Magill et al. 2000).

Single-sided leaf area was estimated as the product of species dry foliar mass from litterfall collection and specific leaf area (SLA). SLA was calculated as the inverse of measured leaf mass per unit area (LMA) determined from green-leaf sampling (see Canopy structure and nitrogen content, below). Leaf-area index (LAI) was calculated as the mean ratio of leaf area and litter-basket ground area (in square meters per square meter).

Canopy structure and nitrogen content.-For determination of growing-season foliar chemistry at each plot, all dominant and co-dominant species were identified, and between two and seven trees per species were selected for green-leaf collection. Leaves were collected by shotgun sampling of small branches from several heights in the canopy. Samples were collected in midsummer to coincide with the peak of the growing season and with overflight of NASA's Airborne Visible/ Infrared Imaging Spectrometer (AVIRIS). Samples were oven dried at $70^{\circ} \mathrm{C}$ for $48 \mathrm{~h}$ and then ground with a Wiley mill to pass through a 1-mm mesh screen. A benchtop visible and near-infrared spectrophotometer (NIRSystems model 6500 [Foss NIRS Systems, Silver Spring, Maryland, USA]) was used to determine leaflevel foliar $\mathrm{N}$ concentrations of oven-dried, ground fo- liage according to methods described by Bolster et al. (1996).

Plot-level whole-canopy nitrogen concentration (grams of $\mathrm{N}$ per $100 \mathrm{~g}$ oven-dried foliar biomass) was calculated as the mean of foliar $\mathrm{N}$ concentration for individual species in each stand, weighted by fraction of canopy foliar mass per species. Each species contribution to the total mass of the canopy was determined by combining its proportional leaf area with LMA measurements.

Determination of species' leaf area fraction in each plot was achieved using a camera-based point quadrat sampling technique in which a $35-\mathrm{mm}$ camera with a 135-mm telephoto lens served as the sampling device. The focal plane of the lens was calibrated to distance in meters to allow use as a range finder, and a grid of 15 points was marked on the camera's viewing screen. In each sample plot the camera, mounted on 1-m-tall tripod, was directed upward towards the canopy and leveled. The species and height of the lowest leaf covering each grid point was determined by focusing the lens and recording the calibrated distance. In each sample plot, 15 grid-point observations were taken at nine sample points for a total of 135 observations per plot. Although not an accurate estimator of total leaf area, this method has been demonstrated to be an accurate means of determining the relative distribution or fraction of leaf area by height (MacArthur and Horn 1969, Aber $1979 a, b)$ and by species (Parker et al. 1989) in a forested canopy.

For determination of species LMA, additional leaf samples were collected from the upper canopy for each dominant or co-dominant species at the time of midsummer green-leaf sampling. Samples were sealed in resealable polyethylene bags for transportation. Singlesided leaf area was measured by two methods. For broad-leaved deciduous species, disks of known area $\left(2.035 \mathrm{~cm}^{2}\right)$ were taken from each leaf by means of a sharpened metal punch. Five to seven disks per leaf were taken from 3-5 leaves per species per sample. For needle-leaved evergreens, projected leaf area was determined by optical planimetry. Fifty to eighty needles per sample were scanned using a high-resolution black and white optical scanner, and image-processing software was used to determine projected leaf area. All leaf samples were dried at $70^{\circ} \mathrm{C}$ for $48 \mathrm{~h}$ and then weighed to the nearest $0.1 \mathrm{mg}$ to allow determination of leaf mass per unit area.

Canopy composition as a fraction of species by leaf area was converted to fraction by mass using measured LMA values for each species. The accuracy of the camera point method in estimation of whole-canopy $\mathrm{N}$ concentration was validated against estimates derived from canopy leaf area and mass obtained directly from leaf litterfall collection (Smith and Martin 2001). The two methods produced nearly identical estimates of massbased $\mathrm{N}$ concentration among sample plots $\left(R^{2}=0.98\right.$, $P<0.000$; data not shown). 
Statistical analysis.-Statistical analyses of plot-level field data were performed using SYSTAT 7.0 (SPSS 1997). Linear regression analyses were used to examine relationships among productivity (wood production and ANPP), canopy nitrogen, foliar mass, and LAI. Although foliar area and mass-based variables and ANPP are not independent, we include analyses among these variables for illustrative purposes, and for comparison with regressions among these variables and wood production, which are independent. The coefficient of determination $\left(R^{2}\right)$, residual plots, and regression $P$ values $(P<0.05)$ were used to identify the best regression models. Coincident regression analyses and equal-slopes analyses were used to test for slope and intercept differences among regression relationships (Klienbaum et al. 1988).

Remote-sensing data.-Hyperspectral remote-sensing data were obtained for the White Mountain region using NASA's Airborne Visible/Infrared Imaging Spectrometer (AVIRIS). Flying aboard an ER-2 aircraft at an altitude of $20000 \mathrm{~m}$, AVIRIS measures upwelling radiance from the solar reflected spectrum in 224 contiguous channels from 0.4 to $2.4 \mu \mathrm{m}$ with a spectral resolution of $0.01 \mu \mathrm{m}$ (Green et al. 1998). On $12 \mathrm{Au}-$ gust 1997 , under nearly cloud-free conditions, fifty-six contiguous $10 \times 10 \mathrm{~km}$ scenes with a spatial resolution of $\sim 17 \mathrm{~m}$ were obtained for the entire White Mountain region. Foliar chemistry data were collected from all sample sites within three days of the AVIRIS overflight. Sample plots were distributed across 36 of 56 scenes that comprise the 1997 WMNF AVIRIS data set.

The atmosphere plays a complex and often confounding role in optical remote sensing, dramatically altering the spectral nature of radiation reaching the sensor (Schowengerdt 1997). Without a robust means of transforming at-sensor radiance to canopy reflectance, accurate retrieval of canopy biochemical properties is not possible. In this study AVIRIS at-sensor radiance data were transformed to apparent surface reflectance using the atmosphere removal program (ATREM) of Gao et al. (1992, 1993). ATREM was designed specifically for retrieving scaled surface reflectance from spectral imaging data collected by the AVIRIS sensor. ATREM uses a radiative transfer model, based on the MODTRAN 5S code (Tanre et al. 1990), to calculate atmospheric transmittance of seven gases (water vapor, ozone, oxygen, carbon monoxide, carbon dioxide, methane, and nitrous oxide). Atmospheric attenuation and scattering effects of these gases are then removed from the images on a pixel-by-pixel basis.

After atmospheric correction, AVIRIS images were resampled to $20-\mathrm{m}$ resolution and then geometrically registered to a geo-coded SPOT panchromatic coverage of the study area (Spot Image Corporation, Reston, Virginia, USA). AVIRIS reflectance spectra for $2 \times 2$ pixel areas covering each sample plot were extracted for spectral analysis. We examined relationships among plot-level spectral response and canopy nitrogen concentration using a full-spectrum analytical method, partial least squares (PLS) regression.

Prior to examination of correlations among spectral data and whole-canopy $\mathrm{N}$ concentration using the fullspectrum PLS method, plot-level reflectance spectra $(\rho)$ were transformed to absorbance $(A)$, where

$$
A=\log _{10}(1 / \rho)
$$

and a derivative transformation (approximated by finite difference) was applied. According to Beer-Lambert, the concentration of an absorber is directly proportional to $A$ where $A$ is the product of molecular absorption, the concentration of absorbers, and the path length of irradiating energy (Murray and Williams 1987). The derivative spectrum is simply a measure of the slope of the spectral curve at every point, and results in a spectrum in which peaks and valleys correspond with inflection points in the absorbance spectra (thus aiding in resolving overlapping spectral peaks) and from which baseline offsets and low-frequency variation (such as are caused in a remote-sensing context by varying sun-sensor-target geometry) have been removed or substantially minimized (Hrushcka 1987). Myneni et al. (1995) demonstrated that in the case of optically dense vegetation, such as that found in closedcanopy forests, the spectral derivative with respect to wavelength can be shown to be directly indicative of the abundance and activity of absorbers in leaves.

PLS regression, a type of eigenvector analysis, was used to relate AVIRIS spectral response to whole-canopy $\mathrm{N}$ concentration data for each sample stand. PLS regression methods reduce full-spectrum data to a smaller set of independent latent variables, or factors, with the constituent concentration data used directly during the spectral-decomposition process (Shenk and Westerhaus 1991). As a result, full-spectrum wavelength loadings for significant PLS factors $(P \leq 0.05)$, from which regression coefficients for each wavelength are derived, are directly related to constituent concentration and thus describe the spectral variation most relevant to the modeling of variation in the chemical data. Finite difference approximations of the derivative transformation, both first and second order, were performed iteratively during PLS regression analysis over variable wavelength widths with the aim of maximizing the squared multiple-correlation coefficient between spectral data and whole-canopy N concentration (Murray and Williams 1987). Values of inflection points are reported at the center point of the smoothed segment.

\section{RESUlts AND Discussion}

\section{Productivity, foliar chemistry, and canopy structure}

Table 1 shows the results of all plot-level field measurements. Aboveground net primary production (ANPP) varied by a factor of 6 across study sites, ranging from 120 to $615 \mathrm{~g} \cdot \mathrm{m}^{-2} \cdot \mathrm{yr}^{-1}$ in needle-leaved ev- 
ergreen dominated stands ( $n=9$ stands) and from 496 to $752 \mathrm{~g} \cdot \mathrm{m}^{-2} \cdot \mathrm{yr}^{-1}$ in broad-leaved deciduous-dominated stands ( $n=9$ stands). Aboveground wood production ranged from 66 to $357 \mathrm{~g} \cdot \mathrm{m}^{-2} \cdot \mathrm{yr}^{-1}$ in evergreen-dominated stands $(n=17)$ and from 260 to $502 \mathrm{~g} \cdot \mathrm{m}^{-2} \cdot \mathrm{yr}^{-1}$ in deciduous-dominated stands $(n=39$ stands). Mean and variance in growth rates among Bartlett Experimental Forest (BEF; Bartlett, New Hampshire, USA) and USDA Forest Service forest inventory and analysis (FIA) plots for similar forest types were not significantly different, suggesting that difference in both measurement interval and inventory approach among plot sets was not a substantial problem. Clark et al. (2001) suggest that it is not measurement interval per se but rather the failure to adequately account for mortality over the interval that is the principal source of error (i.e., underestimation of aboveground biomass) in longinterval estimates of forest production.

Foliar production varied more than five-fold (51-267 $\mathrm{g} \cdot \mathrm{m}^{-2} \cdot \mathrm{yr}^{-1}$ ), and comprised from $18 \%$ to $47 \%$ of ANPP. Leaf-area index (LAI) ranged from 1.73 to 3.61. Foliar production, LAI, and foliar mass all showed greater variation within needle-leaved evergreen-dominated stands than within broad-leaved deciduous-dominated stands, and much of this could be related to variation in leaf retention time.

Canopy $\mathrm{N}$ concentrations (grams of $\mathrm{N}$ per $100 \mathrm{~g}$ foliar biomass) varied more than two-fold across all sites, differing in both mean and range between functional types. Canopy $\mathrm{N}$ ranged from 1.61 to $2.48 \%$ among deciduous-dominated stands $(n=64$ stands, mean $=2.05 \%)$ and from $0.88 \%$ to $1.80 \%$ among evergreen-dominated stands $(n=21$, mean $=1.33 \%)$. Within deciduous-dominated stands, foliar N concentration showed greater relative variation than did LAI and foliar biomass, which varied little. Total canopy $\mathrm{N}$ content (grams of $\mathrm{N}$ in the canopy per square meter of ground surface area) varied more widely across sites (1.00-9.62 $\mathrm{g} / \mathrm{m}^{2}$ ) than did canopy $\mathrm{N}$ concentration, largely reflecting variation in canopy biomass among evergreen-dominated stands.

Across all sites and functional types, whole-canopy foliar $\mathrm{N}$ concentration was the strongest overall predictor for both ANPP and wood production among the variables we measured (Fig. 2, Table 2). Significant linear relationships between productivity (ANPP and wood production) and LAI, foliar mass, and canopy $\mathrm{N}$ content were also found, but the trends differed across functional types in both slope and intercept (Fig. 3, Table 2). Among evergreen-dominated stands, ANPP and wood production also showed strong linear correlations with LAI, foliar biomass ( in grams per square meter) and canopy $\mathrm{N}$ content (in grams per square meter). Among deciduous types, ANPP and wood production were well related to canopy $\mathrm{N}$ content, but were poorly related to canopy mass and showed no relationship with LAI.

Comparison of relationships among canopy variables
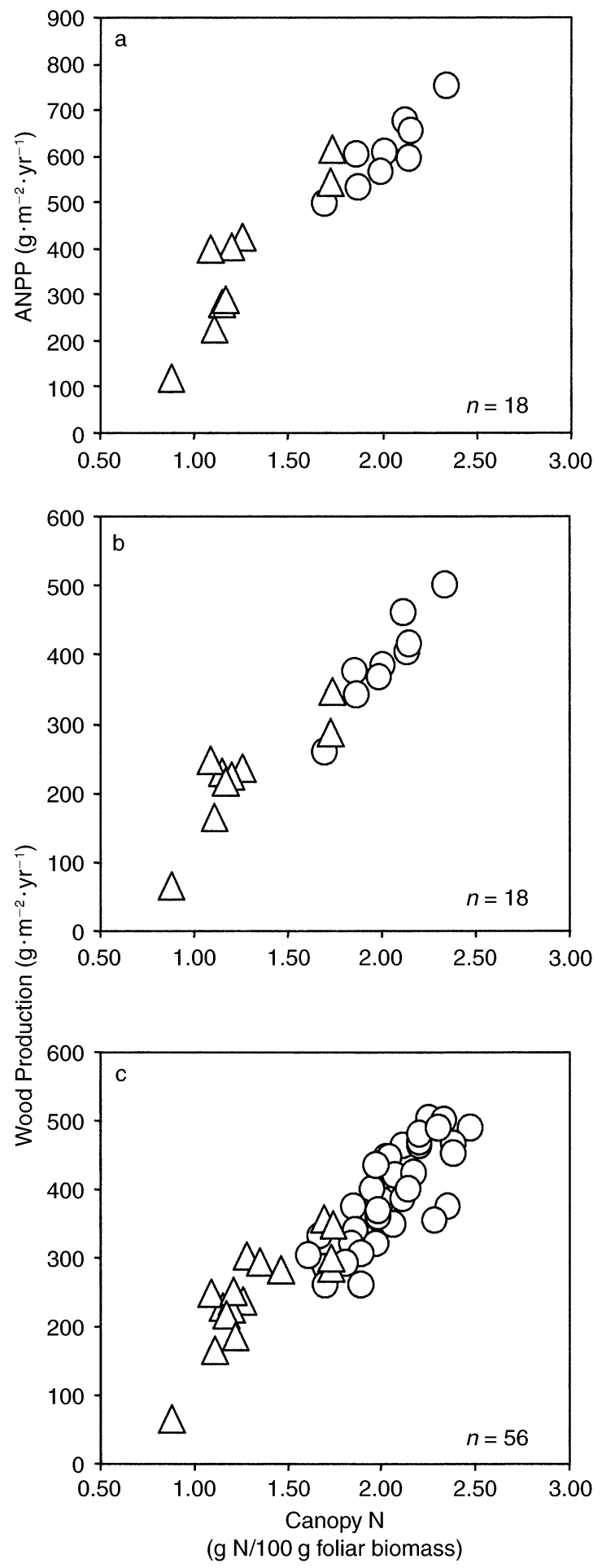

FIG. 2. Relationships among whole-canopy nitrogen concentration and aboveground productivity for broad-leaved deciduous (open circles) and needle-leaved evergreen (open triangles) forest types, White Mountains, New Hampshire, USA. Relationships among canopy-level N concentration and (a) ANPP and (b) wood production for the foliar production data subset ( $n=18$ stands) as well as (c) wood production for the full wood production data set ( $n=56$ stands). 
TABLE 2. Correlation coefficients and regression $P$ values (in parentheses) among measures of aboveground forest productivity and measured canopy variables.

\begin{tabular}{|c|c|c|c|c|c|c|}
\hline \multirow[b]{2}{*}{ Canopy variables } & \multicolumn{3}{|c|}{$\begin{array}{l}\text { Aboveground net primary production } \\
\left(\mathrm{g} \cdot \mathrm{m}^{-2} \cdot \mathrm{yr}^{-1}\right)\end{array}$} & \multicolumn{3}{|c|}{$\begin{array}{c}\text { Aboveground wood production } \\
\left(\mathrm{g} \cdot \mathrm{m}^{-2} \cdot \mathrm{yr}^{-1}\right)\end{array}$} \\
\hline & All & Evergreen & Deciduous & All & Evergreen & Deciduous \\
\hline \multicolumn{7}{|l|}{$\mathrm{N}(\mathrm{g} / 100 \mathrm{~g})$} \\
\hline Full plot data set & $\ldots$ & & $\ldots$ & $0.80(0.00) \dagger$ & $0.66(0.00) \ddagger$ & $0.61(0.00) \S$ \\
\hline Foliar production data set & $0.88(0.00) \|$ & $0.80(0.01) \mathrm{T}$ & $0.78(0.01) \mathbb{I}$ & $0.89(0.00) \|$ & $0.68(0.04) \mathbb{\Phi}$ & $0.86(0.00) \mathscr{I}$ \\
\hline $\mathrm{N}$ content $\left(\mathrm{g} / \mathrm{m}^{2}\right)$ & $\ldots$ & $0.85(0.00) \mathbb{T}$ & $0.82(0.00) \mathbb{I}$ & $\cdots$ & $0.62(0.01) \mathbb{I}$ & $0.55(0.01) \mathscr{I}$ \\
\hline LAI $\left(\mathrm{m}^{2} / \mathrm{m}^{2}\right)$ & $\ldots$ & $0.87(0.00) \mathbb{I}$ & NSII & $\cdots$ & $0.57(0.01) \mathbb{U}$ & NSII \\
\hline Canopy mass $\left(\mathrm{g} / \mathrm{m}^{2}\right)$ & $\ldots$ & $0.85(0.00) \mathbb{I}$ & $0.07(\mathrm{NS}) \mathrm{I}$ & $\ldots$ & $0.53(0.02) \mathscr{I}$ & NSII \\
\hline
\end{tabular}

Notes: Correlations among wood production and canopy $\mathrm{N}$ concentration are presented for the full plot data set $(n=56$ stands), as well as correlations among measured canopy variables, ANPP, and wood production for the foliar production plot subset $(n=18$ stands). NS $=$ nonsignificant at $P \leq 0.05$.

$\dagger$ No. stands used in the measure of forest production $=56$.

$\ddagger$ No. stands $=17$.

$\S$ No. stands $=39$.

$\|$ No. stands $=18$.

II No. stands $=9$.

and productivity between deciduous and evergreen stands may reflect different patterns of resource allocation between the two groups. Previous work has shown that, at the leaf level, photosynthetic capacity tends to be lower per unit foliar $\mathrm{N}$ for evergreen than deciduous temperate forest species (Reich et al. 1995) and is inversely correlated with leaf retention time (Reich et al. 1999a). Similarly, at the canopy level in single-species stands, Gower et al. (1993) showed an inverse correlation between leaf retention time and production efficiency, defined as ANPP per unit LAI. Our data show similar patterns, although plot-level leaf retention time is more difficult to characterize in the mixed-species stands we examined. In addition, our data showed interesting differences in relationships between canopy $\mathrm{N}$ and productivity when canopy $\mathrm{N}$ was expressed as mass-based concentration vs. total $\mathrm{N}$ content. Although both relationships were strong within functional types (and within evergreens represents the strongest trend in our data set), the relationships for canopy $\mathrm{N}$ content differed across functional groups whereas the relationship for canopy $\mathrm{N}$ concentration
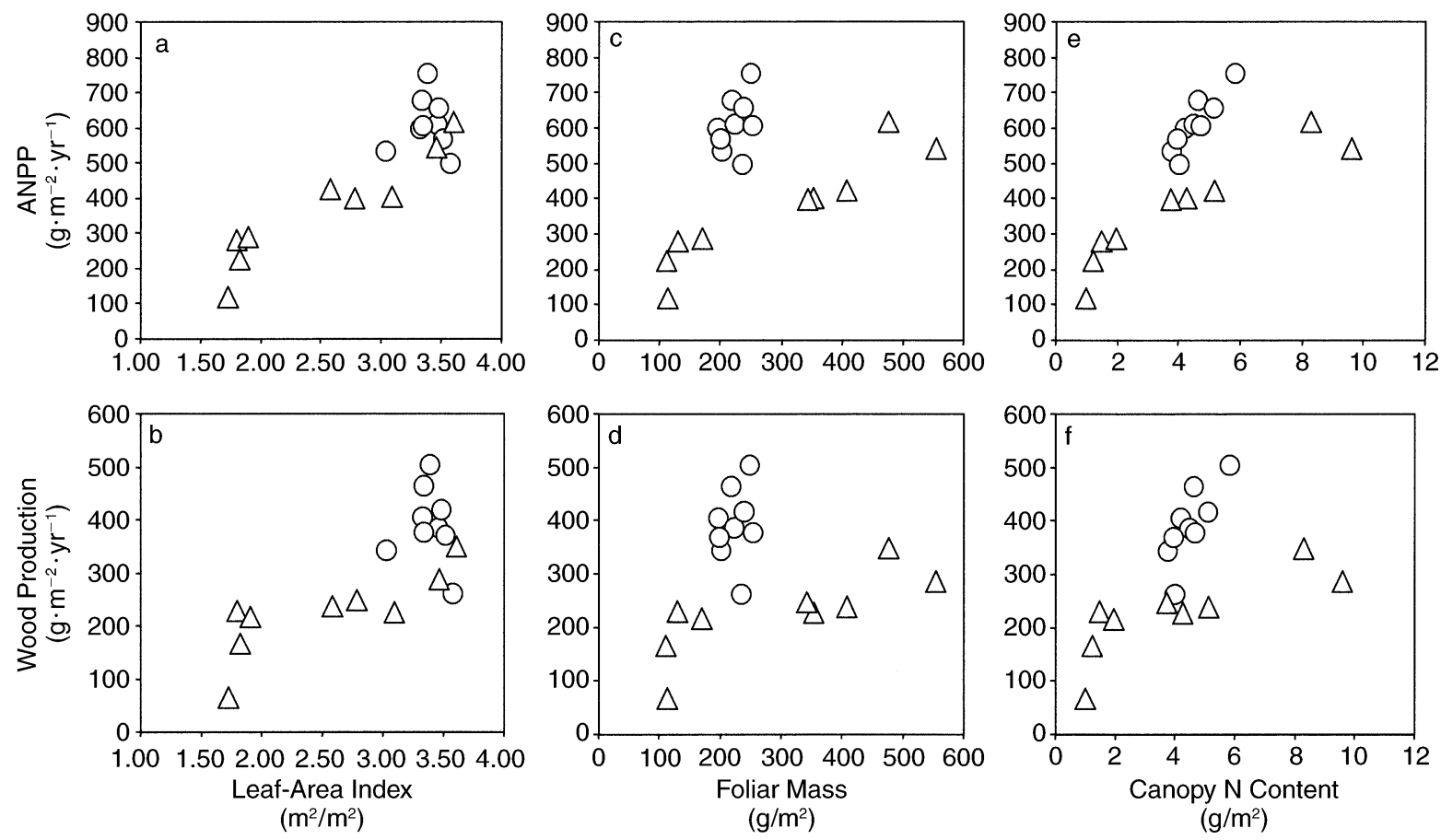

FIG. 3. Relationships among forest productivity (aboveground net primary production [ANPP] and aboveground wood production) and several measured canopy variables for broad-leaved deciduous (open circles) and needle-leaved evergreen (open triangles) forest types, White Mountains, New Hampshire, USA. 
did not (Figs. 2 and 3). Production per unit canopy N content was significantly lower within evergreen-dominated stands than within deciduous-dominated stands. This likely reflects a trade-off in growth strategy whereby evergreen species have lower leaf-level photosynthetic capacity per unit foliar $\mathrm{N}$ than deciduous species (Reich et al. 1995) that may be compensated by their often-greater total foliar biomass.

Neither LAI nor canopy mass in this study were strong linear correlates of productivity across forest types. The use of LAI in particular as a robust linear correlate and hence potential estimator of forest productivity has been most effectively demonstrated within single functional types or across large moisture gradients where substantial variation in LAI can be observed (e.g., Gower et al. 1992, Matson et al. 1994, Fassnacht and Gower 1997). The comparison between forest productivity and LAI in this study suggests that once a certain level of canopy cover is reached (singlesided LAI $\geq 3.0$, in this study) variation in production becomes less well related to LAI. This pattern has been previously shown for both LAI and spectral vegetation indices (SVIs) such as NDVI (normalized-difference vegetation index, from which LAI is often derived in a remote-sensing context) and stems from the fact that as canopy area increases, the light-interception efficiency of additional leaf layers decreases due to increased self-shading (Gower et al. 1993, Reich et al. $1999 b)$. The result is that relationships between growth and LAI (and between LAI and SVIs) often become saturated, typically at LAI values of between 3 and 5 depending on ecosystem type, above which these variables become less tightly coupled (Reich et al. 1999b, Turner et al. 1999). In some systems this is a minor issue, but in closed-canopy forests, it can be an important consideration. In this study this was particularly true among deciduous-dominated stands, which showed relatively little variation in LAI, but considerable, and related, variation in both foliar $\mathrm{N}$ and productivity (ANPP and wood production).

Our data suggest that variation in growth in closedcanopy deciduous forests is related more to variation in physiological properties that reflect leaf-level photosynthetic capacity than to canopy properties such as total foliar biomass or leaf area. That the relationships between productivity and foliar $\mathrm{N}$ were consistent across deciduous and coniferous forests is interesting given their well-documented differences in leaf-level photosynthetic efficiency (photosynthesis per unit foliar N, Reich et al. 1992, 1995, Gower et al. 1993). This suggests that differences in these and other associated leaf traits involve compensating trade-offs that result in similar growth efficiencies at the stand level (e.g., lower leaf-level growth rates among conifers allowing longer leaf retention times, lower respiration rates, and maintenance of greater canopy biomass) (Tilman 1988, Reich et al. 1992). However, this explanation requires that stand-level efficiency be defined per unit leaf nitrogen (which is not necessarily intuitive), or at least that leaf $\mathrm{N}$ concentration is correlated with more appropriate efficiency indices (e.g., litterfall $\mathrm{N}$ as suggested by Vitousek et al [1995]). Hence, we cannot presently resolve why leaf-level $\mathrm{N}$ concentration should scale with wood growth or ANPP more precisely than canopy $\mathrm{N}$ content (or other canopy properties). It is also unclear how generalizeable this relationship may be across other forested regions.

Nevertheless, the challenge of applying LAI to estimation of production in closed-canopy forests, and in particular at fine spatial scales or within regions where moisture regimes and LAI are less variable, suggests that methods for detecting canopy properties that relate instead to the production efficiency of foliage would represent an important addition to current capabilities. Evidence from field studies in diverse biomes has shown mass-based $\mathrm{N}$ concentration to scale positively and at a high level of generality with photosynthetic rate, growth, and productivity across many functional types, at scales from individual leaves to forest stands (Reich et al. 1992, 1995, 1999a). Evidence from lightuse efficiency modeling studies suggests that the observed linear relationship between productivity and fraction of absorbed photosynthetically active radiation $\left(f_{\text {APAR }}\right)$ is largely a function of the optimization of $\mathrm{N}$ allocation within plant canopies (Haxeltine and Prentice 1996, Medlyn 1998), and is particularly strong when expressed on a leaf or canopy mass basis rather than an area basis (see Goetz and Prince 1999). Massbased $\mathrm{N}$ concentration typically remains constant with vertical canopy position (Ellsworth and Reich 1993, O'Neill et al. 2002) and is reasonably stable over the growing season for both deciduous and evergreen species (i.e., post-leaf expansion to late summer) (Martin 1994, Bauer et al. 1997), making characterization through field sampling and, potentially, remote sensing relatively straightforward. The potential utility of a Nbased approach does not imply that production necessarily be $\mathrm{N}$ limited. For example in systems where growth may be limited by other nutrients (e.g., phosphorus), carbon and nitrogen cycles often remain coupled through maintenance of conservative nutrient ratios in plants and through the dependence of $\mathrm{N}$ cycling on plant organic-matter production (e.g., Vitousek et al. 1995).

\section{Canopy chemistry and AVIRIS spectral response}

Based on results from our field data, our analysis of AVIRIS spectral data focused primarily on whole-canopy $\mathrm{N}$ concentration as the most straightforward and general remote-sensing approach. Whole-canopy $\mathrm{N}$ concentration was the strongest linear correlate of productivity across the forest types we examined, and no a priori knowledge of forest composition was required for application of the empirical correlation with image spectral data.

Correlation or calibration (Hruschka 1987) of AVIR- 
TABLE 3. Summary statistics for partial least squares (PLS) regression of canopy nitrogen concentration (grams of $\mathrm{N}$ per $100 \mathrm{~g}$ foliar biomass) with AVIRIS spectral response within and across AVIRIS scenes.

\begin{tabular}{lcccccccc}
\hline \hline $\begin{array}{c}\text { No. } \\
\begin{array}{c}\text { AVIRIS } \\
\text { scenes } \dagger\end{array}\end{array}$ & $\begin{array}{c}\text { PLS } \\
\text { factors }\end{array}$ & Math $\ddagger$ & $N \S$ & $R^{2}$ & SE $_{\text {CV } \|}$ & CVII & $\begin{array}{c}\text { Mean N } \\
\text { concen- } \\
\text { tration }\end{array}$ & Range \\
\hline $1(\mathrm{BEF})$ & 3 & $1,4,3$ & 44 & 0.84 & 0.23 & 0.13 & 1.81 & $0.88-2.48$ \\
36 & 3 & $1,4,3$ & 53 & 0.82 & 0.25 & 0.13 & 1.88 & $0.88-2.48$ \\
\hline
\end{tabular}

$\dagger$ Single-scene calibration is based on sample and spectral data from the Bartlett Experimental Forest (BEF), New Hampshire, USA; multi-scene calibration is based on sample and spectral data from 36 of 56 AVIRIS scenes across the White Mountain National Forest, New Hampshire, USA.

\$ Mathematical transformation of spectral data, where the first number is the order of the derivative function, the second is the segment length in data points over which the derivative was taken, and the third the segment length over which the function was smoothed.

$\S N=$ no. of plots.

$\| \mathrm{SE}_{\mathrm{CV}}=$ Standard error of cross-validation, the square root of the mean square of the residuals for $n-1$ degrees of freedom; it is calculated based on an iterative exclusion and prediction of each sample.

II Coefficient of variation, ratio of $\mathrm{SE}_{\mathrm{CV}}$ to the mean $\mathrm{N}$ concentration.

IS spectral response with measured whole-canopy $\mathrm{N}$ concentration was undertaken at two spatial resolutions. A single-scene calibration (10-km² area) focused on plot sample and spectral data from the BEF. A multiscene calibration included canopy $\mathrm{N}$ concentration and spectral data distributed across 36 of 56 AVIRIS scenes covering the White Mountain National Forest. For the multi-scene calibration, field and spectral data from 32 of 44 sample plots from the BEF data set were excluded in order to minimize spectral-calibration bias from any one scene. Included BEF spectral data represent the range in spectral response over the forest types sampled and were chosen based on an objective population structuring method that ranks an individual spectrum based on Mahalanobis distance $(H)$ from an average spectrum of the population (Shenk and Westerhaus 1991). Excluded samples were reserved as a validation data set for multi-scene calibration.

Using full-spectrum PLS regression we obtained two 3 -factor calibration equations, one single-scene and one multi-scene equation, relating AVIRIS spectral response to measured whole-canopy N concentration (Table 3). Strong correlations among measured whole-canopy $\mathrm{N}$ concentration and transformed AVIRIS absorbance spectra were found both within $\left(R^{2}=0.84\right)$ and across $\left(R^{2}=0.82\right)$ scenes and could be associated with absorption features in both the visible and near infrared spectrum as indicated by the magnitude of factor loadings associated with specific wavelength regions (Fig. 4). Important absorption features in the visible region have direct association with photosynthetic pigments, primarily broad chlorophyll absorption features centered near $490 \mathrm{~nm}$ and $680 \mathrm{~nm}$ (Curran 1989). Spectral features at near infrared wavelengths centered at 1150 $\mathrm{nm}, 1510 \mathrm{~nm}, 1740 \mathrm{~nm}$, and $2050 \mathrm{~nm}$ represent overtones of fundamental absorption characteristics of $\mathrm{N}$ $\mathrm{H}$ and $\mathrm{C}-\mathrm{H}$ bonds at longer wavelengths that are associated with leaf proteins and which differ from those of other major leaf components (Curran 1989, Barton et al. 1992).

Nitrogen, which is typically a small percentage of leaf biomass, has been repeatedly correlated in a number of empirical investigations of forest canopies with absorbance over the spectral regions identified in this study (e.g., Matson et al. 1994, Martin and Aber 1997, White et al. 2000). Evidence from canopy modeling and radiative-transfer studies suggests that leaf optical properties (and thus foliar chemistry) are expressed most strongly at the canopy level when canopies are optically dense-that is, closed canopies of high LAI, which are typical of many forested systems. As noted previously, Myneni et al. (1995) were among the first to describe the physical and theoretical basis for high spectral-resolution remote sensing of canopy chemistry in the case of optically dense vegetation. Recent evidence from combined field data and radiative-transfer modeling studies provide support for this conclusion. For example, Asner (1998) in a combined field-data and canopy-reflectance modeling study examined the influence of varying LAI and LAD (leaf angle distribution) on the translation of leaf-level information including foliar chemistry ( $N$, lignin, and cellulose) to the canopy level for sites ranging from grasslands to savannas to tropical woodlands. He found that leaf optical properties, and hence leaf-level biochemistry, could be represented in canopy reflectance in both the visible and near-infrared (NIR) regions via the narrowband absorption features of derivative spectra. LAI and leaf angle control the strength of this expression, which varies by ecosystem type. In general he found that closed canopies of high LAI and of generally horizontal leaf inclination (characteristics of the temperate deciduous and mixed-conifer forests that are the subject of this study) best allow the generally weak leaf-level biochemical information, particularly in the NIR, to be enhanced at the canopy scale via multiple scattering. 


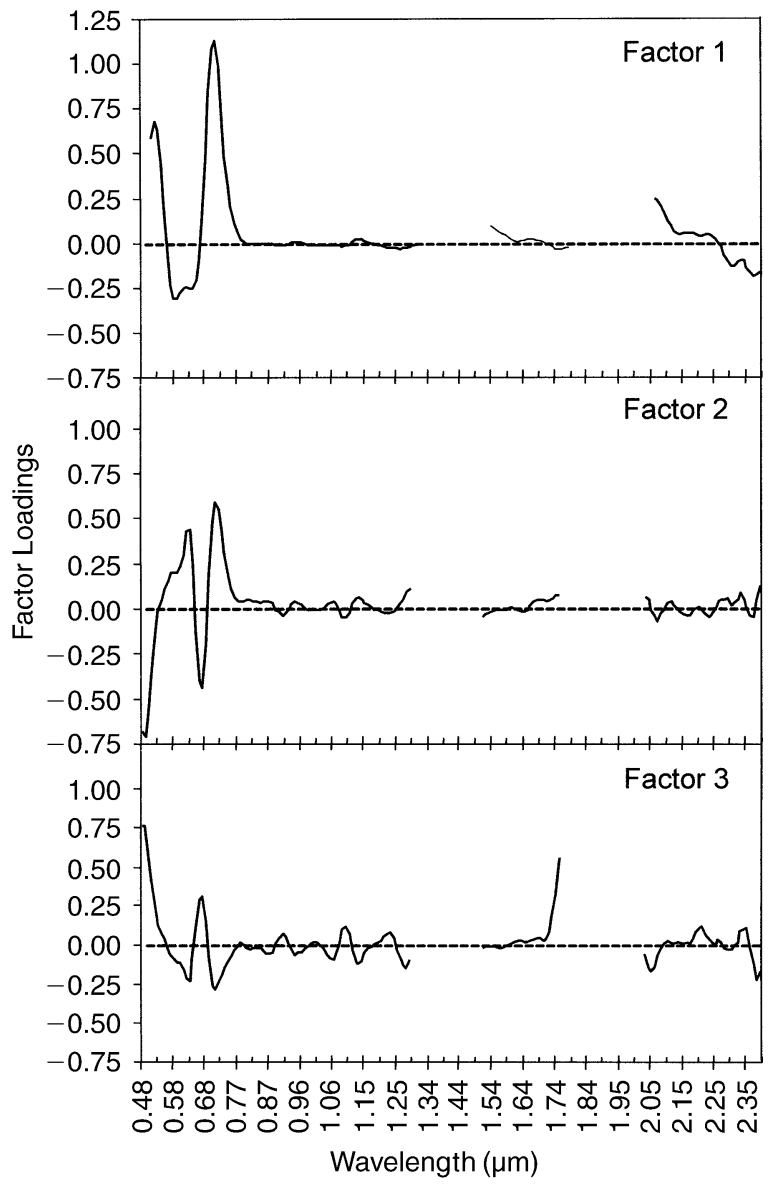

FIG. 4. Results of partial least squares (PLS) regression for 53 forest canopy nitrogen concentration calibration samples among 36 AVIRIS scenes. Latent variables (loadings) of the first three significant PLS factors are plotted against wavelength, excluding wavelength regions associated with strong water-absorption features. Together these factors account for $82 \%$ of the variability in $\mathrm{N}$ concentration (Table 2), each factor accounting for $53 \%, 23 \%$, and $6 \%$ of the variability, respectively. Important wavelength regions for prediction of canopy $\mathrm{N}$ concentration are those in the visible range centered near $0.49 \mu \mathrm{m}$ and $0.68 \mu \mathrm{m}$ associated with cholorphyll absorption features, and those in the near-infrared centered near $1.15 \mu \mathrm{m}, 1.51 \mu \mathrm{m}, 1.74 \mu \mathrm{m}$, and $2.05 \mu \mathrm{m}$ associated with protein and nitrogen absorption features.

Similarly, Gastellu-Etchegorry and Bruniquel-Pinel (2001) used a combined leaf- and canopy-level radiative-transfer modeling approach to assess the robustness of spectrometric predictive equations for the estimation of the canopy chemistry of forested stands when applied to scenes of varying structural characteristics (percent cover, LAI). Predictive equations were developed for lignin, cellulose, and proteins using spectral absorbance features in the 1300-2400 nm region. For all chemical constituents, predictive equations performed well for forest canopies of percent cover $>48 \%$ and LAI $>2.5$. These equations yielded robust predictions when applied to scenes of higher LAI or greater tree cover, but the reliability of these equations decreased strongly when applied to scenes of smaller LAI or diminished tree cover (i.e., increasing understory variability).

In this study, results of PLS regression represent the first successful derivation of a single calibration equation for the prediction of forest canopy-level $\mathrm{N}$ concentration across multiple hyperspectral images. Both single- and multi-scene calibrations developed by this method for these data fall well within the accuracy and precision required for mapping variation in foliar $\mathrm{N}$ necessary to distinguish between ecosystems in their photosynthetic and, hence, productive potential (i.e., within $0.5 \%$ by dry mass as described by Schimel [1995]). We attribute this success in particular to the improved radiometric precision of the AVIRIS sensor in conjunction with a careful, multi-step field data-toimage calibration process (including pixel by pixel atmospheric correction), and to the use of the PLS regression method for calibration-equation derivation.

The radiometric precision and accuracy of the AVIRIS sensor is very high and continues to improve from year to year. A recent laboratory calibration and inflight validation and sensitivity experiment (Green et al. 1999) demonstrated an absolute average agreement (accuracy) of $>96 \%$ across the spectrum between predicted and observed AVIRIS radiance for a known calibration target. The signal-to-noise ratio (SNR) of AVIRIS is an equally important parameter of interest. Calculated based on AVIRIS measurements of homogenous targets and using AVIRIS radiance data from 1987 as the baseline, Green et al. (1999) report AVIRIS SNR of better than 1000 to 1 in the visible portion of the spectrum, better than 600 to 1 in the $1000 \mathrm{~nm}$ region, and approaching 450 to 1 in the $2000 \mathrm{~nm}$ spectral region. This is in contrast to AVIRIS SNR in 1987 that was much less than 100 to 1 in most spectral regions.

The advantage of PLS regression in multi-image calibration lies in its use of the full spectral coverage in each factor rather than reliance on a few selected wavelengths (as in the more commonly used multiple linear regression (MLR) calibration), and in the direct relationship between regression factors and the constituent of interest rather than simply with the largest common spectral variation (Kramer 1998). Thus, PLS regression calibration is likely to be more robust with small calibration data sets and to variation in target composition, illumination, and path length-factors that, when using an MLR approach in remote spectroscopy contexts, often produce inconsistent calibration wavelength selection from sample set to sample set (see Grossman et al. 1996, White et al. 2000).

\section{Nitrogen concentration and $f_{\mathrm{APAR}}$}

A number of studies aimed at remote detection of ecosystem productivity have focused on direct relationships between growth and the fraction of absorbed photosynthetically active radiation (e.g., Monteith 


\section{a) Whole-canopy nitrogen concentration (\%)}
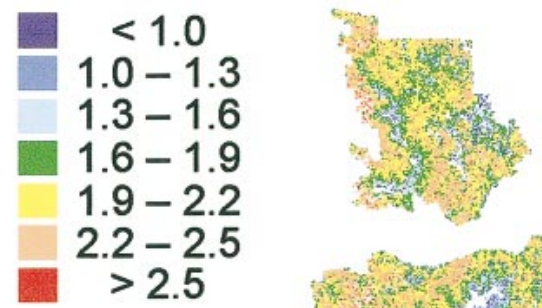

$2.2-2.5$
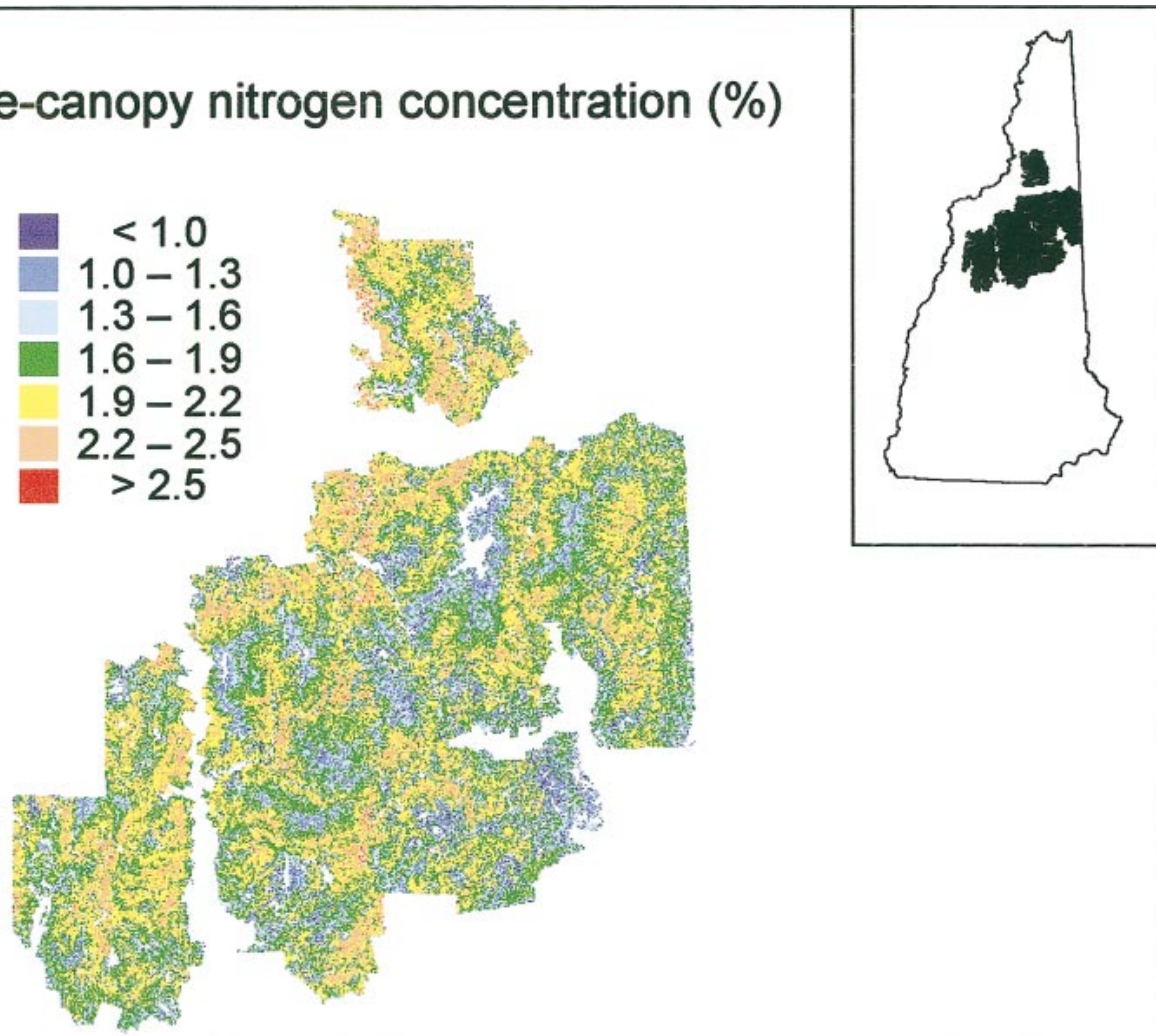

b) Aboveground woody biomass production $\left(\mathrm{g} \cdot \mathrm{m}^{-2} \cdot \mathrm{yr}^{-1}\right)$
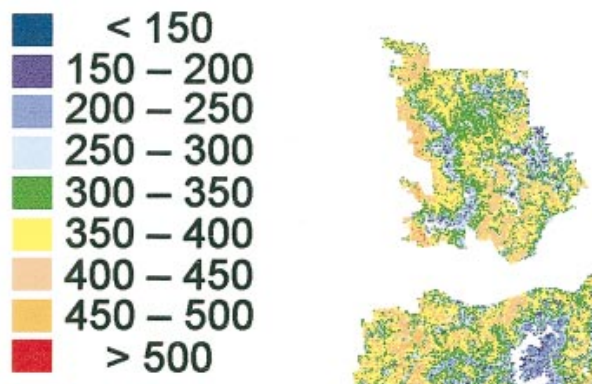

$>500$

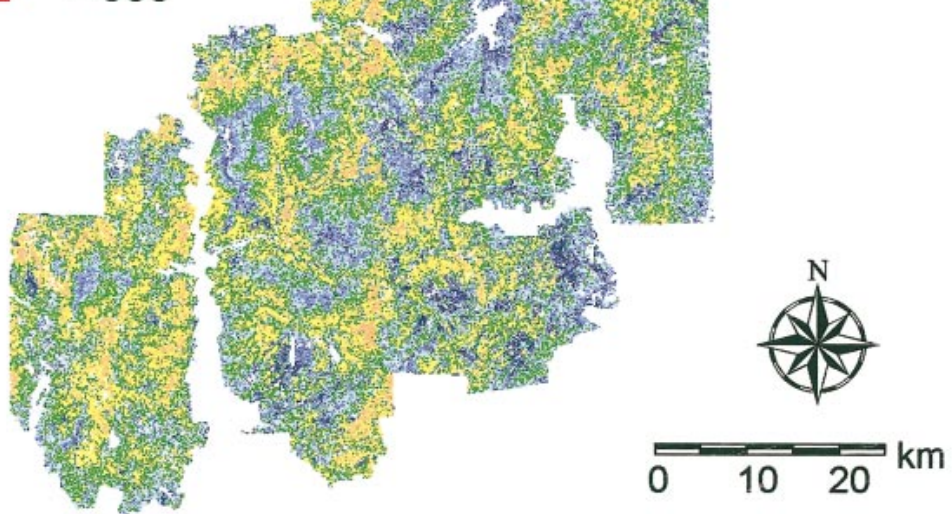

FIG. 5. Spatial distribution of (a) AVIRIS-predicted nitrogen concentrations ( $\mathrm{g} \mathrm{N} / 100 \mathrm{~g}$ foliar biomass) for the White Mountain National Forest, New Hampshire, USA (see inset of the state of New Hampshire) and (b) aboveground wood production, as estimated from AVIRIS predicted whole-canopy $\mathrm{N}$ concentration. 
1972, Runyon et al. 1994, Prince and Goward 1995). This approach is generally known as the light-use efficiency model (NPP $\left.=\varepsilon f_{\mathrm{APAR}}\right)$, where $f_{\mathrm{APAR}}$ is the fraction of absorbed photosynthetically active radiation and $\varepsilon$ is the light-use efficiency constant. Although this method and the one we present in this paper appear to bear little direct relationship, the development of the two methods have a similar basis and are not necessarily inconsistent. For example, Myneni et al. (1995) used a radiative-transfer model to examine the functional basis of linkages between SVIs, $f_{\mathrm{APAR}}$, and growth. They determined that in optically dense plant canopies, common vegetation indices, insofar as they approximate the spectral derivative, should reflect the activity and abundance of light absorbers in the canopy, which are largely a function of chlorophyll and other nitrogen-based pigments. The link between $f_{\mathrm{APAR}}$ and LAI, which has been used as a more intermediate scalar in a number of subsequent analyses (e.g., Myneni et al. 1997, Knyazikhin et al. 1999), assumes that the content of absorbers in a plant canopy is more dependent on the number of leaf layers present than on the concentrations of absorbers within individual leaves. While this approach has been successful in a number of cases, and may be the most practical approach globally, our data suggest that closed-canopy deciduous forests may vary their leaf-level physiology (i.e., N concentration) more than their total leaf area.

In addition, although a great deal of effort has gone into estimating and interpreting light-use efficiency constants for different biomes (see Gower et al. 1999), considerable uncertainties still exist. Goetz and Prince (1999) discussed the possibility that common evolutionary constraints imposed on all plants should lead towards convergence on a relatively narrow range of $\varepsilon$. Other authors have noted the wide range of measured values (published values of $\varepsilon$ range from $\sim 0.2$ to over 3.5 g/MJ [Medlyn 1998]) and have devoted considerable attention to explaining this variation. Our data raise the possibility that foliar $\mathrm{N}$ may play an important role here, a notion that has previously been suggested by a number of other investigators (e.g., Cannell et al. 1988, Wright et al. 1993). Because examining $f_{\mathrm{APAR}}$ and canopy light-use efficiency were beyond the scope of our study, we only speculate on the relationships among these variables and leaf- and whole-canopy N.

\section{AVIRIS estimation of whole canopy $N$ concentration and wood production}

The statistical relationship derived from multi-scene PLS regression described in Table 3 was used in conjunction with AVIRIS data to produce a map of forest canopy $\mathrm{N}$ concentration for the White Mountain National Forest (Fig. 5a), and thus, using the relationship in Fig. 2c, a map of wood production (Fig. 5b). The same approach can be applied to Fig. 2a to map patterns of ANPP. Wood production is presented here because the data set upon which the wood-production regres- sion is based is larger and because more independent validation data were available for wood growth than for ANPP. These variables scale linearly with one another given that wood growth is the largest component of ANPP and our field data showed wood and leaf production to be strongly correlated $\left(R^{2}=0.55\right.$, data in Table 1).

Image spatial patterns broadly reflect the distribution of functional types. Broad-leaved deciduous species dominate areas with foliar $\mathrm{N}$ concentration $>1.9 \%$, needle-leaved evergreens dominate those below $1.3 \%$, and intermediate areas are of mixed-forest type. Finescale spatial variation results from a variety of natural and anthropogenic factors including species successional sequences, historic and current land use, disturbance regime, and soil type (Goodale and Aber 2001, Ollinger et al. 2002).

Whole-canopy $\mathrm{N}$ concentration data from the BEF, reserved from multi-scene calibration equation development, provides some means of assessing the accuracy of the AVIRIS predictive equations with independent data. A plot of field-measured vs. AVIRIS-predicted values of canopy $\mathrm{N}$ concentration for BEF plots reserved from multi-scene regression (Fig. 6a.) shows generally good agreement $\left(R^{2}=0.71\right.$, SEE $\left.=0.19\right)$, with some tendency towards under-prediction at the high end of the range.

Likewise, independent field measurements of the control watershed (W6) at the Hubbard Brook Experimental Forest (New Hampshire, USA) (Whittaker et al. 1974) and more recently the Cone Pond (New Hampshire, USA) watershed (J. W. Hornbeck, unpublished data) which both lie within the WMNF provide a limited independent-evaluation data set for AVIRISderived wood production estimates (Fig. 6b.). AVIRISderived estimates for Hubbard Brook W6 are an area average for the watershed and are thus directly comparable to the area-weighted estimates for W6 reported by Whittaker et al. (1974). Estimates for Cone Pond are based on $2 \times 2$ pixel averages around each of nine 0.04-ha plots clustered in three sample areas, one deciduous forest sample area and two areas of evergreen spruce-fir forest. Field-based productivity values for Cone Pond were measured over successive growing seasons between 1987 and 1991 .

For the spruce-fir forest sites at the Cone Pond watershed, field-measured estimates of wood production are 211,143 , and $127 \mathrm{~g} \cdot \mathrm{m}^{-2} \cdot \mathrm{yr}^{-1}$ in one sample area and 228,203 , and $211 \mathrm{~g} \cdot \mathrm{m}^{-2} \cdot \mathrm{yr}^{-1}$ in the second sample area. AVIRIS-predicted values for these conifer sites are 160,172 , and $157 \mathrm{~g} \cdot \mathrm{m}^{-2} \cdot \mathrm{yr}^{-1}$ for the former and 189,197 , and $205 \mathrm{~g} \cdot \mathrm{m}^{-2} \cdot \mathrm{yr}^{-1}$ for the latter.

Field-measured wood production values for the predominantly broad-leaved deciduous control watershed at Hubbard Brook range from 529 to $423 \mathrm{~g} \cdot \mathrm{m}^{-2} \cdot \mathrm{yr}^{-1}$ (based on Whittaker et al. [1974] stem wood + branch wood measures for the periods 1956-1960 and 19611965 , respectively) vs. AVIRIS-predicted wood pro- 

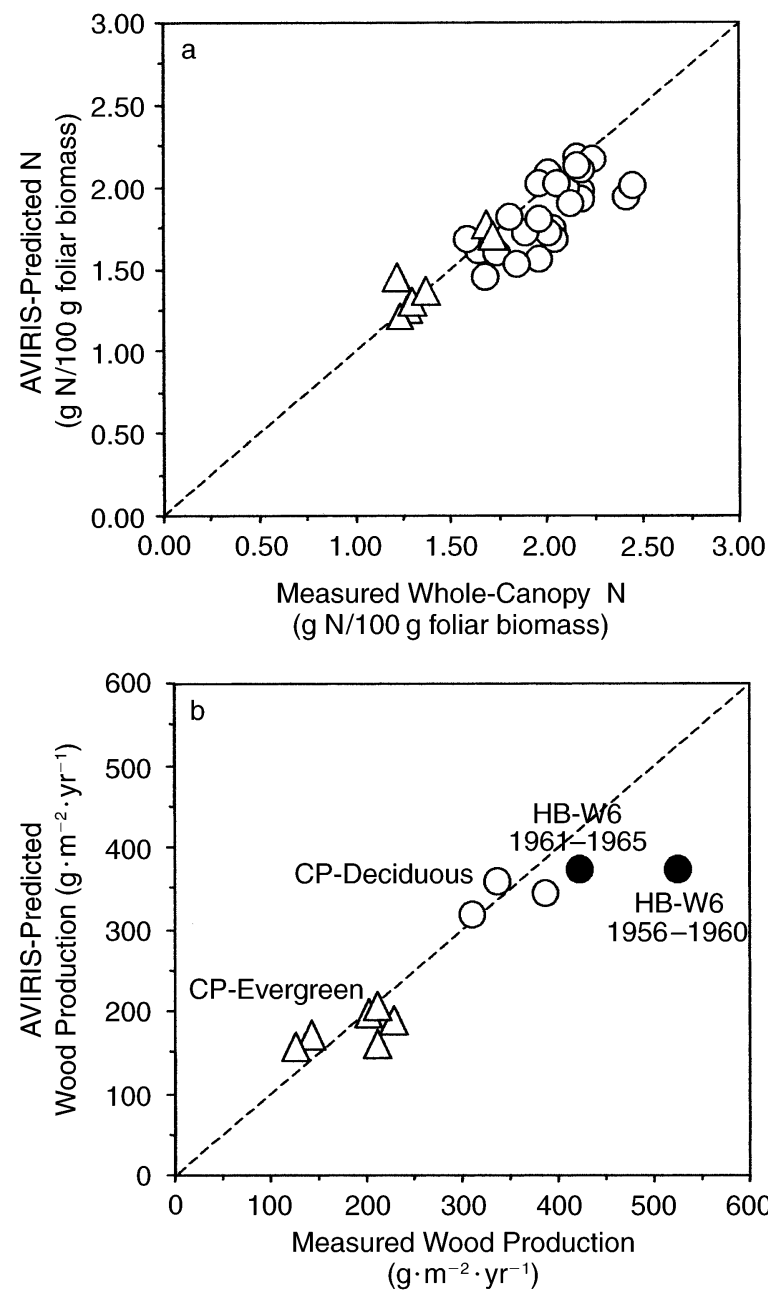

FIG. 6. AVIRIS-predicted values for (a) whole-canopy nitrogen concentration in relation to measured values for 32 forest stands from the Bartlett Experimental Forest, New Hampshire, USA, not included in the multi-scene AVIRIS calibration $\left(R^{2}=0.71\right.$, SEE $\left.=0.19\right)$ and (b) aboveground wood production in relation to independent measures from the Hubbard Brook Experimental Forest (New Hampshire, USA; solid circles) and Cone Pond (New Hampshire, USA; open circles and triangles) watersheds $\left(R^{2}=0.86\right.$, SEE $=$ 31.49). Measures from Hubbard Brook represent two measurement periods, 1956-1960 and 1961-1965. In both panels, circles represent broad-leaved deciduous-dominated forest sites and triangles represent needle-leaved evergreen-dominated forest sites; dashed lines represent the 1:1 relationship.

duction of $371 \mathrm{~g} \cdot \mathrm{m}^{-2} \cdot \mathrm{yr}^{-1}$. For similar forested stands at Cone Pond, measured wood production values are 338,313 , and $388 \mathrm{~g} \cdot \mathrm{m}^{-2} \cdot \mathrm{yr}^{-1} \mathrm{vs}$. AVIRIS-predicted values of 357,317 , and $341 \mathrm{~g} \cdot \mathrm{m}^{-2} \cdot \mathrm{yr}^{-1}$, respectively.

The larger difference in AVIRIS-predicted vs. measured wood production values for Hubbard Brook W6 relative to those predicted for Cone Pond may be due to the much longer time interval between field measurements and AVIRIS image acquisition at Hubbard Brook W6 than at Cone Pond, and to mean stand age at time of field measurement. Stands at Hubbard Brook
W6 were between 40 and $60 \mathrm{yr}$ of age at the time of measurement in the early- to mid-1960s (stands at Cone Pond were more than $100 \mathrm{yr}$ old at time of measurement), thus the apparent reduction in the rate of forest production at Hubbard Brook W6 detected via remote sensing may reflect a natural successional or age-related decline (see Gower et al. 1996) in the rate of forest growth as this forest approaches maturity, i.e., stand ages of 80-100 yr in northern hardwood forests of New England (Hornbeck and Leak 1992).

Although our analysis was not designed to address this question directly, results from this and a related study indicate several potentially competing mechanisms by which growth rates might change over time. In forest ecosystems, succession typically involves early dominance by species with a suite of associated traits, including high foliar nitrogen, high photosynthetic capacity, low shade tolerance, high relative growth rates, and short life-span (Bazzaz 1979, Tilman 1988, Reich et al. 1992). Species characteristic of latersuccessional communities tend to exhibit contrasting properties (e.g., lower foliar N, increased shade tolerance, etc.) indicative of reduced rates of physiological activity and increased life-span. Foliar N concentration for the species examined in our study are consistent with this pattern, with early successional species (e.g., pin cherry and paper birch) tending to have higher foliar $\mathrm{N}$ concentration and shorter life-spans than latersuccessional, shade-tolerant species such as sugar maple and American beech (Smith and Martin 2001, Ollinger et al. 2002). Given the canopy N-productivity trends shown in Fig. 2, we might expect that productivity should decline over time given the increasing dominance of species that generally have lower foliar $\mathrm{N}$.

However, this explanation is relatively simplistic and ignores variation in foliar $\mathrm{N}$ that can occur within species in response to differences in soil properties and disturbance history. In a study that focused on patterns of $\mathrm{N}$ cycling in White Mountain forest ecosystems, Ollinger et al. (2002) examined species-level leaf $\mathrm{N}$ concentrations with respect to soil $\mathrm{N}$ availability and found that both may vary as a function of stand age and history. For deciduous stands, leaf $\mathrm{N}$ concentration for a given species were often higher in old and relatively undisturbed stands than in younger stands of similar species composition in earlier stages of recovery from some major disturbance (clear-cutting or fire). This was attributed to disturbance effects on $\mathrm{N}$ mineralization. In other words, while there are differences in foliar $\mathrm{N}$ concentration between species that vary predictably over the course of succession (and may be reflected through time in forest growth rates), large differences in foliar $\mathrm{N}$ concentration can also occur within species due to disturbance history and soil fertility gradients. Variation in canopy $\mathrm{N}$ concentrations across the White Mountain region as estimated from AVIRIS spectral response integrates the effects of these 
and perhaps other factors, so without specific knowledge of species distribution, site history, etc., it is impossible to draw strong conclusions about changes in forest growth over time from these data alone.

In aggregate, AVIRIS-predicted values for these independent productivity data show good agreement with measured values $\left(R^{2}=0.86\right.$, SEE $\left.=31.42 \mathrm{~g} \cdot \mathrm{m}^{-2} \cdot \mathrm{yr}^{-1}\right)$, and predicted values fall well within the observed precision with which wood production can be measured by this method at the stand level $(\mathrm{SEE}=38.31$ $\mathrm{g} \cdot \mathrm{m}^{-2} \cdot \mathrm{yr}^{-1}$, see Table 1 and Fig. 2c). Although such modest evaluation data sets are clearly not adequate for a land area as large as the WMNF, this initial effort does demonstrate the potential of hyperspectral image data to detect with reasonable accuracy and precision important components of forest ecosystem function across a large and heterogeneous landscape.

\section{ACKNOWLEDGMENTS}

This research was conducted as part of the White Mountain MAPBGC project (Mapping and Analysis of Productivity and Biogeochemical Cycling) with support from NASA under the joint program on Terrestrial Ecology and Global Change (NAG5-3527), the U.S. EPA under the STAR program (R825865), and the USDA Forest Service Northern Global Change Program. The project was conducted in cooperation with the USDA Forest Service, Northeastern Forest Inventory and Analysis Program, Newtown Square, Pennsylvania, USA. We gratefully acknowledge the help of the staff of the White Mountain National Forest, especially that of Steve Fay. We thank Jim Hornbeck and Bob Smith for use of previously unpublished data from the Cone Pond, New Hampshire, USA, watershed. We also thank the many individuals who have helped with the often arduous tasks of data collection and laboratory analysis, including Jim Muckenhoupt, Jennifer Pontius, Gloria Quigley, Alison Magill, Melissa Sytek, Shannon Cromley, Ralph Perron, John Pontius, Matt Kislinski, Mark Riddell, Adam Wilson, Alex Sherman, Tracey Freuder, and Lauren Hallett.

\section{Literature Cited}

Aber, J. D. 1979a. A method for estimating foliage-height profiles in broad-leaved forests. Journal of Ecology 67:3540.

Aber, J. D. 1979b. Foliage-height profiles and succession in northern hardwood forests. Ecology 60:18-23.

Aber, J. D., J. M. Melillo, K. J. Nadelhoffer, J. Pastor, and R. Boone. 1991. Factors controlling nitrogen cycling and nitrogen saturation in northern temperate forest ecosystems. Ecological Applications 1:303-315.

Asner, G. P. 1998. Biophysical and biochemical sources of variability in canopy reflectance. Remote Sensing of Environment 64:234-253.

Barton, F. I., D. Himmelsbach, J. Duckworth, and M. Smith. 1992. Two-dimensional vibration spectroscopy: correlation of mid- and near-infrared regions. Applied Spectroscopy 46(3):420-429.

Battle, M., M. L. Bender, P. P. Tans, J. W. C. White, J. T. Ellis, T. Conway, and R. J. Francey. 2000. Global carbon sinks and their variability inferred from atmospheric $\mathrm{O}_{2}$ and $\delta \delta^{13} \mathrm{C}$. Science 287:2467-2470.

Bauer, G., E.-D. Schulze, and M. Mund. 1997. Nutrient contents and concentrations in relation to growth of Picea abies and Fagus sylvatica along a European transect. Tree Physiology 17:777-786.

Bazzaz, F. A. 1979. The physiological ecology of plant suc- cession. Annual Review of Ecology and Systematics $\mathbf{1 0}$ 351-371.

Bolster, K. L., M. E. Martin, and J. D. Aber. 1996. Determination of carbon fraction and nitrogen concentration in tree foliage by near infrared reflectance: a comparison of statistical methods. Canadian Journal of Forest Research 26:590-600.

Cannell, M. G. R., L. J. Shepperd, and R. Milne. 1988. Light use efficiency and woody biomass production of poplar and willow. Forestry 61:125-126.

Clark, D. A., S. Brown, D. W. Kicklighter, J. Q. Chambers, J. R. Thomlinson, and J. Ni. 2001. Measuring net primary production in forests: concepts and field methods. Ecological Applications 11:356-370.

Comeau, P. G., and J. P. Kimmins. 1986. The relationship between net primary production and foliage nitrogen content, and its application in the modeling of forest ecosystems: a study of lodgepole pine (Pinus contorta). Pages 202-223 in T. Fujimori and D. Whitehead, editors. Crown and canopy structure in relation to productivity. Forestry and Forest Products Research Institute, Ibaraki, Japan.

Curran, P. 1989. Remote sensing of foliar chemistry. Remote Sensing of Environment 30:271-278.

Ellsworth, D., and P. Reich. 1993. Canopy structure and vertical patterns of photosynthesis and related leaf traits in a deciduous forest. Oecologia 96:169-178.

Fassnacht, K. S., and S. T. Gower. 1997. Interrelationships among the edaphic and stand characteristics, leaf area index, and aboveground net primary production of upland forest ecosystems in north central Wisconsin. Canadian Journal of Forest Research 27:1058-1067.

Federer, C. A., L. E. Flynn, C. W. Martin, J. W. Hornbeck, and R. S. Pierce. 1990. Thirty years of hydrometeorologic data at the Hubbard Brook Experimental Forest, New Hampshire. USDA Forest Service, General Technical Report NE-141.

Field, C., and H. A. Mooney. 1986. The photosynthesisnitrogen relationship in wild plants. Pages $25-55$ in T. J. Givnish, editor. On the economy of plant form and function. Cambridge University Press, Cambridge, UK.

Fung, I. Y. 1997. A greener north. Nature 386:659-660.

Gao, B., K. B. Heidebrecht, and F. H. Goetz. 1992. Atmosphere removal program (ATREM) user's guide. Center for the Study of Earth from Space/CIRES, University of Colorado, Boulder, Colorado, USA.

Gao, B., K. B. Heidebrecht, and A. Goetz. 1993. Derivation of scaled surface reflectances from AVIRIS data. Remote Sensing of Environment 44:165-178.

Gatellu-Etchegorry, J. P., and V. Bruniquel-Pinel. 2001. A modeling approach to assess the robustness of spectrometric predictive equations for canopy chemistry. Remote Sensing of Environment 76:1-15.

Gillon, D., C. Houssard, and R. Joffre. 1999. Using near infrared reflectance spectroscopy to predict carbon, nitrogen, and phospherous content in heterogeneous plant material. Oecologia 118:173-182.

Goetz, S. J., and S. D. Prince. 1999. Modelling terrestrial carbon exchange and storage: evidence and implications of functional convergence in light-use efficiency. Advance in Ecological Research 28:57-92.

Goodale, C. L., and J. D. Aber. 2001. The long-term effects of land-use history on nitrogen cycling in northern hardwood forests. Ecological Applications 11:253-267.

Gower, S. T., C. J. Kucharik, and J. M. Norman. 1999. Direct and indirect estimation of leaf area index, $f_{\mathrm{APAR}}$, and net primary production of terrestrial ecosystems. Remote Sensing of Environment 70:29-51.

Gower, S. T., R. E. McMurtrie, and D. Murty. 1996. Aboveground net primary production decline with stand age: po- 
tential causes. Trends in Ecology and Evolution 11:378382.

Gower, S. T., P. B. Reich, and Y. Son. 1993. Canopy dynamics and aboveground production of five tree species with different leaf longevities. Tree Physiology 12(4):327-345.

Gower, S. T., K. A. Vogt, and C. C. Grier. 1992. Carbon dynamics of Rocky Mountain douglas fir: influence of water and nutrient availability. Ecological Monographs 62 43-65.

Green, R. O., M. L. Eastwood, C. M. Sarture, T. G. Chrien, M. Aronsson, B. J. Chippendale, J. A. Faust, B. E. Pavri, C. J. Chovit, M. Solis, M. R. Olah, and O. Williams. 1998. Imaging spectrometry and the airborne visible/infrared imaging spectrometer (AVIRIS). Remote Sensing of Environment 65:227-248.

Green, R. O., B. Pavri, J. Faust, and O. Williams. 1999. AVIRIS radiometric laboratory calibration, inflight validation, and a focused sensitivity analysis in 1998. Pages 161-175 in R. O. Green, editor. Summaries of the Eighth JPL Airborne Earth Sciences Workshop. JPL Publication 99-17. National Aeronautics and Space Administration, Pasadena, California, USA.

Grossman, Y. L., S. L. Ustin, S. Jacquemond, E. W. Sanderson, G. Schmuck, and J. Vandebout. 1996. Critique of stepwise linear regression for the extraction of leaf biochemistry information from leaf reflectance data. Remote Sensing of Environment 56:182-193.

Hallett, R. A., M. E. Martin, and J. W. Hornbeck. 1997. Predicting elements in white pine and red oak foliage with near infrared reflectance spectroscopy. Journal of Near Infrared Spectroscopy 5:77-82.

Hansen, M. H., T. Frieswyk, J. F. Glover, and J. F. Kelly. 1992. The eastwide forest inventory database: users manual. USDA Forest Service, General Technical Report NC151

Haxeltine, A., and I. C. Prentice. 1996. A general model for the light-use efficiency of primary production. Functional Ecology 10:551-561.

Hocker, H. W., and D. J. Early. 1983. Biomass and leaf area equations for northern forest species. Research report 102 New Hampshire Agricultural Experiment Station, Durham, New Hampshire, USA.

Hornbeck, J. W., and W. B. Leak. 1992. Ecology and management of northern hardwood forests in New England. USDA Forest Service, General Technical Report NE-159.

Houghton, R. A., J. L. Hackler, and K. T. Lawrence. 1999. The U.S. carbon budget: contributions from land-use change. Science 285:574-578.

Hrushcka, W. R. 1987. Data analysis: wavelength selection methods. Pages 39-58 in P. Williams and K. Norris, editors Near-infrared technology in the agricultural and food industries. Second edition. American Association of Cerea Chemists, Saint Paul, Minnesota, USA.

Klienbaum, D. G., L. L. Kupper, and K. E. Muller. 1988. Applied regression analysis and other multivariable methods. PWS-Kent Publishing, Boston, Massachusetts, USA.

Knyazikhin, Y., J. Glassy, J. L. Privette, Y. Tian, A. Lotsch, Y. Zhang, Y. Wang, J. T. Morisette, P. Votava, R. B. Myneni, R. R. Nemani, and S. W. Running. 1999. MODIS leaf area index (LAI) and fraction of photosynthetically active radiation (FPAR) product (MOD15) alogrithim theoretical basis document. [Online, URL: 〈http://modis.gsfc.nasa gov/data/atbd/atbd_mod15.pdf $\rangle$.]

Kramer, R. 1998. Chemometric techniques for quantitative analysis. Marcel Dekker, New York, New York, USA.

Leak, W. B., and M. L. Smith. 1996. Sixty years of management and natural disturbance in a New England forested landscape. Forest Ecology and Management 81:63-73.

MacArthur, R. H., and H. S. Horn. 1969. Foliage profile by vertical measurements. Ecology 50:802-804.
Magill, A. H., J. D. Aber, G. M. Berntson, W. H. McDowell, K. J. Nadelhoffer, J. M. Melillo, and P. A. Steudler. 2000. Long-term nitrogen additions and nitrogen saturation in two temperate forests. Ecosystems 3:238-253.

Martin, M. E. 1994. Measurements of foliar chemistry using laboratory and airborne high spectral resolution visible and infrared data. University of New Hampshire, Durham, New Hampshire, USA.

Martin, M. E., and J. D. Aber. 1997. High spectral resolution remote sensing of forest canopy lignin, nitrogen, and ecosystem processes. Ecological Applications 7:431-443.

Matson, P. A., L. Johnson, C. Billow, J. Miller, and R. Pu. 1994. Seasonal patterns and remote spectral estimation of canopy chemistry across the Oregon transect. Ecological Applications 4:280-298.

Medlyn, B. E. 1998. Physiological basis of the light use efficiency model. Tree Physiology 18:167-176.

Montieth, J. L. 1972. Solar radiation and production in tropical systems. Journal of Applied Ecology 9:747-766.

Murray, I., and P. Williams. 1987. Chemical principles of near-infrared technology. Pages 17-34 in P. Williams and K. Norris, editors. Near-infrared technology in the agricultural and food industries. Second edition. American Association of Cereal Chemists, Saint Paul, Minnesota, USA.

Myneni, R. B., F. G. Hall, P. J. Sellers, and A. L. Marshak. 1995. The interpretation of spectral vegetation indexes. IEEE Transactions on Geoscience and Remote Sensing 33: 481-486.

Myneni, R. B., R. R. Nemani, and S. W. Running. 1997. Estimation of global leaf area index and absorbed PAR using radiative transfer models. IEEE Transactions on Geoscience and Remote Sensing 35:1380-1393.

Ollinger, S. V., M. L. Smith, M. E. Martin, R. A. Hallet, C. L. Goodale, and J. D. Aber. 2002. Regional variation in foliar chemistry and soil nitrogen status among forests of diverse history and composition. Ecology 83:339-355.

O'Neill, A. L., J. A. Kupiec, and P. J. Curran. 2002. Biochemical and reflectance variation throughout a Sitka spruce canopy. Remote Sensing of Environment 80:134142.

Parker, G. G., J. P. O’Neil, and D. Higman. 1989. Vertical profile and canopy organization in a mixed deciduous forest. Vegetatio 85:1-11.

Pastor, J., J. D. Aber, C. A. McClaugherty, and J. Mellilo. 1984. Aboveground production and $\mathrm{N}$ and $\mathrm{P}$ cycling along a nitrogen mineralization gradient on Blackhawk Island, Wisconsin. Ecology 65:256-268.

Prince, S. D., and S. N. Goward. 1995. Global primary production: a remote sensing approach. Journal of Biogeography 22:815-835.

Reich, P. B., D. S. Ellsworth, M. B. Walters, J. M. Vose, C. Gresham, J. C. Volin, and W. D. Bowman. 1999a. Generality of leaf traits relationships: a test across six biomes. Ecology 80:1955-1969.

Reich, P. B., D. F. Grigal, J. D. Aber, and S. T. Gower. 1997. Nitrogen mineralization and aboveground net primary production in 50 stands in a cold-temperate forest biome. Ecology 78:335-347.

Reich, P., B. Kloeppel, D. Ellsworth, and M. Walters. 1995. Different photosynthesis-nitrogen relations in deciduous hardwood and evergreen coniferous tree species. Oecologia 104:24-30.

Reich, P. B., D. P. Turner, and P. Bolstad. 1999b. An approach to spatially distributed modeling of net primary production (NPP) at the landscape scale and its application in validation of EOS NPP products. Remote Sensing of Environment 70:69-81.

Reich, P., M. Walters, and D. Ellsworth. 1992. Leaf life-span in relation to leaf, plant, and stand characteristics among diverse ecosystems. Ecological Monographs 62:365-392. 
Runyon, J., R. H. Waring, S. N. Goward, and J. M. Welles. 1994. Environmental limits on primary production and light-use efficiency across the Oregon transect. Ecological Applications 4:226-237.

Schimel, D. 1995. Terrestrial biogeochemical cycles: global estimates with remote sensing. Remote Sensing of Environment 51:49-56.

Schimel, D. S., VEMAP participants, and B. H. Braswell. 1997. Continental scale variability in ecosystem processes: models, data, and the role of disturbance. Ecological Monographs 67:251-271.

Schowengerdt, R. A. 1997. Remote sensing: methods and models for image processing. Academic Press, New York, New York, USA.

Scott, N. A., and D. Binkley. 1997. Foliage litter quality and annual net $\mathrm{N}$ mineralization: comparison across North American forest sites. Oecologia 111:151-159.

Scurlock, J. M. O., W. Cramer, R. J. Olson, W. J. Parton, and S. D. Prince. 1999. Terrestrial NPP: toward a consistent data set for global model evaluation. Ecological Applications 9:913-919.

Shenk, J., and M. Westerhaus. 1991. Population structuring of near infrared spectra and modified partial least squares regression. Crop Science 31:1548-1555.

Smith, M. L., and M. E. Martin. 2001. A plot-based method for rapid estimation of forest canopy chemistry. Canadian Journal of Forest Research 31:549-555.

SPSS. 1997. Systat 7.0. SPSS, Chicago, Illinois, USA.

Tanré, D., C. Deroo, P. Duhaut, M. Herman, J. J. Morcette, J. Perbos, and P. Y. Deschamps. 1990. Description of a computer code to simulate the satellite signal in the solar spectrum: the $5 \mathrm{~S}$ code. International Journal of Remote Sensing 11:659-668.

Tilman, D. 1988. Plant strategies and the dynamics and structure of plant communities. Princeton University Press, Princeton, New Jersey, USA.

Tritton, L. M., and J. W. Hornbeck. 1981. Biomass equations for major tree species of the Northeast. USDA Forest Service, General Technical Report NE-69.

Turner, D. P., W. B. Cohen, R. A. Kennedy, K. S. Fassnacht, and J. M. Briggs. 1999. Relationships between leaf area index and Landsat TM spectral vegetation indices across three temperate zone sites. Remote Sensing of Environment 70:52-68.

Van Cleve, K., R. Oliver, L. A. Schlenter, and C. T. Dryness. 1983. Production and nutrient cycling in taiga forest ecosystems. Canadian Journal of Forest Research 13:747-766.

Vitousek, P. M., D. R. Turner, and K. Kitayama. 1995. Foliar nutrients during long-term soil development in Hawaiian montane rain forest. Ecology 76:712-720.

Wessman, C. A., J. D. Aber, D. L. Peterson, and J. M. Melillo. 1988. Remote sensing of canopy chemistry and nitrogen cycling in temperate forest ecosystems. Nature 335:154156.

White, J. D., C. M. Trotter, L. J. Brown, and N. Scott. 2000. Nitrogen concentration in New Zealand vegetation foliage derived from laboratory and field spectroscopy. International Journal of Remote Sensing 21:2525-2531.

Whittaker, R. H., F. H. Bormann, G. E. Likens, and T. G. Siccama. 1974. The Hubbard Brook ecosystem study: forest biomass and production. Ecological Monographs 44: 233-254.

Wright, G. C., M. J. Bell, and G. L. Hammer. 1993. Leaf nitrogen content and minimum temperature interactions affect radiation-use efficiency in peanut. Crop Science 33: 476-481.

Yin, X. 1992. Empirical relationships between temperature and nitrogen availability across North American forests. Canadian Journal of Forest Research 22:707-712.

Zagolski, F., V. Pinel, J. Romier, D. Alcayde, J. P. GastelluEtchegorry, G. Giordano, G. Marty, and E. Mougin. 1996. Forest canopy chemistry with high spectral resolution remote sensing. International Journal of Remote Sensing 17: 1107-1128. 